\title{
İbrahim Anlaşmaları Sonrası Arap Yarımadasının Jeopolitik Analizi ve Türk Büyük Stratejisinin Imkânları/Kısıtları
}

\author{
The Geopolitical Analysis of Arabian Peninsula \\ and the Opportunities/Limits of Turkish Grand Strategy \\ in the Aftermath of Abraham Accords
}

\author{
Ceyhun ÇİÇEKÇI*
}

$\ddot{O} z$

Son yillarda Arap yarmadası devletleri bölgesel ve küresel politikada hiç olmadı̆ğ kadar büyük bir rol oynamaya baslladllar. Özellikle Suudi Arabistan, Birleşik Arap Emirlikleri ve Bahreyn kendileriyle Türkiye arasinda köklü bir jeopolitik rekabet yaratan bölgesel çatısmalara ulusal çlkarlarm gerçekleştirebilmek için dâhil oldular. Bugün, Türk diş ve güvenlik politikasindaki belki de en önemli sorun, Orta Doğu ve Doğu Akdeniz'deki Arap muhalefetidir. Bu soruna optimum bir cevap üretmek temelde Arap yarmadast devletlerinin jeopolitik bir tavorla yeniden değerlendirilmelerini gerektirir. Mackinder, Spykman ve Mahan’ $n$ yeniden ölçeklendirilen teorilerine referansla bu çalssma, Arap yarmadası devletlerini klasik jeopolitiğin kavramlarna yerlestirmektedir. Bunu yaparak bu çahlsma, son zamanlarda ortaya çıkan jeopolitik meydan okumalarn üstesinden gelebilmesi için Türk tarafina birkaç münasip politika önerisi üretmektedir. Son olarak Türkiye'deki büyük strateji tarttşmalarnna özel bir referansla, olası Türk büyük stratejisinin imkânlar ve kısttlan kesfedilecektir.

Anahtar Kelimeler: Klasik feopolitik, Büyük Strateji, Türkiye, Arap Yarmadası, İbrahim Anlassmaları.

\section{Abstract}

In recent years, Arabian peninsula states have started to play a bigger role in regional and global politics than ever before. Particularly Saudi Arabia, United Arab Emirates, and

* Öğr. Gör. Dr., Bandırma Onyedi Eylül Üniversitesi, Erdek Meslek Yüksek Okulu, Yerel Yönetimler Program1, Samsun, Türkiye, ORCID: 0000-0002-5036-537X, e-posta: ccicekci@bandirma.edu.tr.

Geliş Tarihi / Submitted: 23.02.2021

Kabul Tarihi / Accepted: 15.07.2021 
Bahrain were involving the regional conflicts to realize their national interests, which created a radical geopolitical rivalry between them and Turkey. Today, maybe the most important problem in Turkish foreign and security policy is the Arabian opposition in the Middle East and East Mediterranean. Improving an optimum response to this problem basically needs a reevaluation of the Arabian peninsula states in a geopolitical manner. With reference to the rescaled theories of Mackinder, Spykman, and Mahan, this study places the Arabian peninsula states in the concepts of the classical geopolitics. By doing so, this study produces a few policy recommendations to Turkish side to deal with the recently emerged geopolitical challenges. Lastly, with a special reference to grand strategy debates in Turkey, the opportunities and limits of possible Turkish grand strategy will be explored.

Keywords: Classical Geopolitics, Grand Strategy, Turkey, Arabian Peninsula, Abraham Accords.

\section{Giriş}

Orta Doğu coğrafyası, yirminci yüzyıl boyunca uluslararası ilişkiler çalışmalarının temel çalışma nesnelerinden biri olarak konumlanmış ve bölge üzerine devasa bir literatür kaleme alınmıştır. Jeopolitik yaklaşımlar da Orta Doğu coğrafyasının anlaşılabilmesi noktasında işlevselleştirilen bir araç kiti olarak görülmelidir. Bu çalışma da cari Arap jeopolitiğini klasik jeopolitik metinlere ve düşünürlere referanslarla yeniden okuma çabası içerisindedir.

Söz konusu jeopolitik bir çerçeve üretme ihtiyacı, özellikle son yıllardaki gelişmeler sebebiyle elzem bir hal almıştır. Söz konusu gelişmeler, Arap dünyasında bugünlere kadar görülmemiş düzeyde radikal dönüşümlere işaret etmektedirler. Özellikle 2010 yılının son günlerinde patlak veren halk hareketleriyle şekillenen Arap Baharı, 2015 yılında İran'ın uluslararası toplumla entegrasyonunu temsil eden Nükleer Anlaşma ve 2020 yllında İsrail ile BAE ve Bahreyn arasında imzalanan İbrahim Anlaşmaları, Arap jeopolitiğinin yeni bir form kazanmasında önemli köşe taşları olarak işlev gördüler.

Bir başka radikal dönüşüm ise daha ziyade sistemik bir seviyede yaşanmaktadır. Bu bağlamda, küresel güç dengelerinde yaşanan dönüşümün bölgesel yansımaları, Arap yarımadasının merkezinde olduğu coğrafi alanı da yoğun bir biçimde etkilemektedir. Özellikle Amerikan gücünün artık tescillenen düşüşü, Orta Doğu'ya yönelik ilgisinin azalmasını ve Asya-Pasifik bölgesinde küresel bir hegemonya mücadelesine yoğunlaşmasını beraberinde getirmiştir. Alternatif yakıt türlerinin keşfedilmesi sonucunda, yirminci 
yüzyılın diplomatik düzlemde belirleyici bir silahı olarak petrolün de göreceli olarak ayrıcalıklı statüsünü kaybetmesi, Amerikan gücünün Orta Doğu özelindeki hegemonik statüsünde esnek davranışlar sergilemesini kolaylaştırmıştır. Böylece artık, Arap yarımadasının merkezinde olduğu coğrafyada Amerikan gücünün ancak caydırıcılık eksenli bir politika takip edebiliyor olması, bölge jeopolitiğinde sıfır-toplamlı oyunların gündeme gelme ihtimalini arttırmaktadır. Bu çalışma da söz konusu sistemik dönüşümün ve bu dönüşümün bölgesel yansımalarının bir neticesi olarak bölgesel düzeyde iddialı dış politik perspektiflere sahip devletlerden biri olarak Türkiye'nin yeni pozisyonlanmalarına yönelik bir değerlendirme çabasını önemsemektedir.

Orta Doğu olarak isimlendirilen coğrafyanın kalpgâhı (heartland) olarak anılabilecek konumdaki Arap yarımadası, bu süreçte de göreceli olarak edilgen konumunu muhafaza etmiştir ve yakın çevresindeki bölgesel gelişmelere ya da küresel ölçekli güç dengelerindeki dönüşüme tabi bir pozisyon almıştır. Özellikle yukarıda anılan radikal gelişmeler, Arap yarımadasındaki devletlerin dış politika davranışlarını ve ulusal güvenlik algılarını hızlı bir biçimde değiştirmiştir. Günümüzde süregiden bu trend, hem Arap yarımadasını merkezi bir konuma yerleştirmiş hem de bu yarımadadaki devletlerin proaktif dış politikaları kapsamında yeniden bir değerlendirmeye tabi tutulmaları gereğini ortaya çıkarmıştır. Bu çalışmanın temel amaçlarından birisi de söz konusu cari jeopolitik görünümün klasik metinlere atıfla değerlendirmesini yapmak ve geliştirilecek analitik çerçeve içerisinde Türk büyük stratejisi için optimum bir konum aramaktır.

$\mathrm{Bu}$ çalışmanın yapılmasındaki temel motivasyon kaynağ 1 olarak Türkiye'nin bölgesel imkânları, özellikle değerlendirilmesi gereken bir alt başlık niteliği taşımaktadır. Dişişleri Bakanlığı Stratejik Araştırmalar Merkezi tarafından yayına hazırlanan Perceptions isimli akademik derginin Ocak 2021 tarihli sayısı, Türkiye'nin büyük stratejisine ayrılmıştı. Bu sayı kapsamında yayınlanan makalelerden özellikle biri, Türkiye'nin Orta Doğu coğrafyasında pozisyon alabilmesinin başat yollarını tartışan Şener Aktürk'ün makalesiydi. Bu makalesi çerçevesinde Aktürk, Türkiye'nin Orta Doğu özelindeki büyük stratejisinde Suriye ayağına özel bir önem 
atfetmektedir. ${ }^{1}$ Aktürk'ün çalışmasıyla da koşut olarak belki tamamlayıcı bir çaba olarak görülebilecek bu çalışma, Türk büyük stratejisinin özellikle bir silsilenin son halkası olarak İbrahim Anlaşmaları'yla farklı bir görünüm sunan Arap jeopolitiğindeki imkânlarını tartışmayı da hedeflemektedir.

Bu çalışmada, klasik jeopolitiğin mihenk taşları olarak görülebilecek birtakım kavramlar ve kuramlardan istifade edilerek Arap yarımadasına merkezi bir konum atfedilmektedir. Bu bağlamda, kalpgâh, rimland (Kenar Kuşak) ve deniz hâkimiyeti olarak bilinen yaklaşımlar, Arap coğrafyasına uygulanacaktır. Arap yarımadasının cari jeopolitiği, imkânları ve kısıtlılıkları, analitik bir çerçeve içerisinde konumlandırılmaya çalışılacaktır. Ayrıca bütün bu süreçlerin Türk diş politikasına tesirleri de ele alınacak ve son zamanlarda hararetli bir hal alan büyük strateji tartışmalarına değinilerek Türk büyük stratejisinin söz konusu Arap kalpgâhının jeopolitiğindeki eylem kapasitesi üzerine değerlendirmelerde bulunulacaktır.

\section{Arap Kalpgâhının Jeopolitik Analizi}

Jeopolitik kuramların hızlı bir biçimde geliştiği bir dönem olarak yirminci yüzyıl başlarında İngiliz coğrafyacı Sir Halford Mackinder, büyük güçler arasındaki büyük oyuna ithafen dünya hâkimiyetinin imkânları/kısıtlllıkları üzerine düşünmüş ve bir devletin dünyaya hâkim bir konuma gelebilmesi için kalpgâh olarak isimlendirdiği coğrafi alanın kontrol altına alınması gereğini vurgulamıştır. Elbette ki bu öneri, henüz uluslararası kurumsallaşmanın gerçekleşmediği ve dolayısıyla uluslararası hukukun devletleri sınırlayamadığı bir atmosferde ortaya atılmıştır. Günümüzde jeopolitik perspektiflerin yeniden gündeme gelmesi on dokuzuncu yüzyılla kurulabilecek sistemik bir analojiye dayanmaktadır. Öncelikle Çin'in ve diğer Avrasyalı büyük güçlerin liberal uluslararası sisteme meydan okuması çok kutuplu bir dünya düzenine dair tartışmaları ve haliyle jeopolitik yaklaşımları yeniden gündeme getirmekte ve güçlendirmektedir.

Bu bağlamda kalpgâh kavramı, Mackinder'in bugün Sibirya'daki Rus stepleri ve genel hatlarıyla Orta Asya'ya yayılan bir coğrafi alanı

1 Şener Aktürk, "Turkey's Grand Strategy as the Third Power: A Realist Proposal", Perceptions: Journal of International Affairs, Cilt 25 Say1 2, 152-177, p. 152-177. 
İbrahim Anlaşmaları Sonrası Arap Yarımadasının Jeopolitik Analizi ve Türk Büyük Stratejisinin İmkânları/Kısıtları

tanımlayabilmek için kullandığı bir formülasyonu ifade eder. ${ }^{2}$ Kalpgâh, Rus gücünün hâkim olduğu Orta Asya bölgesinin doğal kaynaklar açısından oldukça zengin bir coğrafya olması hasebiyle, büyük güçler tarafından elde edilmesi gereken bir alan olduğuna işaret eder. Hatta bu zenginlikleri sebebiyle bir "ödül” olarak da kodlanır ve büyük güçlerin temel hedeflerinden biri olması gerektiği salık verilir. ${ }^{3}$

Mackinder'in formüle ettiği kalpgâh kavramı çerçevesinde Orta Asya bölgesinin belirgin nitelikleri, söz konusu edilgen pozisyonun tasdikleyicisi rolü oynar. Bu bölgenin karasal bir alana hapsolmuş olması taşımacılığa uygun bir nehir sistemine sahip olmaması ve açık denizlerle herhangi bir irtibatının bulunmaması söz konusu kalpgâhın merkezinden herhangi bir gücün neşet edemeyeceği varsayımını doğrulamaktadır. ${ }^{4} \mathrm{Bu}$ çerçevede de bakıldı̆̆ında söz konusu edilgenlik daha da berraklaşır. Bölge ancak bir dış gücün denetimine girdiği takdirde anlam kazanacaktır. Bir diğer ifadeyle, büyük güçler bölgenin kontrolünü elde ederlerse Orta Asya'nın zengin kaynakları vesilesiyle, güçlerini maksimize etme imkânına sahip olacaklardır. ${ }^{5}$

Mackinder kuramının devamında, günümüzde fazlasıyla klişeleşmiş bir deyimle, Doğu Avrupa bölgesine hâkim olanın kalpgâha hâkim olacağını, kalpgâh bölgesine hâkim olanın dünya adasına hâkim olacağını dünya adasına hâkim olanın da dünyaya hükmedeceğini varsayar. ${ }^{6} \mathrm{Bu}$ formülasyona göre ilk olarak Doğu Avrupa'ya ve sonrasında kalpgâha hâkim olmak gerekmektedir. Mackinder önerdiği sıralamayla, Doğu Avrupa'nın kontrolünden ve kalpgâhtan başlayan ve adım adım dünya hâkimiyetine giden yolu tarif eder. Lakin nihayetinde Mackinder, daha ziyade büyük güçlere büyük emellerini gerçekleştirebilmeleri doğrultusunda fikir vermektedir. Bu çalışma, bir benzeştirime giderek Orta Asya bölgesine atfedilen tanımı Arap yarımadasına uyarlayacaktır. Bir diğer ifadeyle, Mackinder'in küresel

2 H. J. Mackinder, "The Geographical Pivot of History", The Geographical Journal, Vol. 23, No. 4, April 1904, 421-437.

3 Zbigniew Brzezinski, The Grand Chessboard: American Primacy and Its Geostrategic Imperatives, Basic Books, 1997, p. 30.

${ }^{4}$ Mackinder, a.g.e., p. 429.

${ }^{5}$ Brzezinski, a.g.e., p. 39-40.

${ }^{6}$ H. J. Mackinder, Democratic Ideals and Reality: A Study in the Politics of Reconstruction, Henry Holt and Company, New York, 1919, p. 186. 
hâkimiyeti hedefleyen kuramını yeniden ölçeklendirerek Arabistan yarımadasının merkezini teşkil ettiği Arap kalpgâhına uygulayacaktır.

Arap kalpgâhı olarak isimlendirilen alan, aslında Arabistan Yarımadası'nın büyük bölümünü kapsamaktadır. Bu bağlamda devletler üzerinden yapılabilecek bir coğrafi işaretlemeyle, kavrayış kolaylığı sağlanabilir. Bu çerçevede, Birleşik Arap Emirlikleri (BAE), Suudi Arabistan ve Bahreyn Arap kalpgâhını oluşturan teritoryal sınırları göstermesi bakımından sayılabilecek ülkelerdir. Söz konusu ülkelerin bir diğer ortak paydaları ise Körfez İşbirliği Konseyi çerçevesinde bölgesel bir güvenlik örgütü çatısı altında kısmi bir entegrasyon sürecinin parçaları olmalarıdır. 1980'li yılların başında daha ziyade Irak ve İran'dan kaynaklanan tehditleri dengeleyebilmek adına kurulmuş oluşum Suudi Arabistan'ın fiili liderliğinde devam ettirilmektedir.

Analitik olarak tasnif edilmeleri gerekirse; Katar, Kuveyt ve Ürdün'ün bu küme içerisine alınmaması dış politikalarında daha dengeli ve Arap kalpgâhı olarak isimlendirilen ülkeler topluluğundan çoğu zaman farklılaşan bir tutum göstermeleriyle alakalıdır. Hâlbuki Arap kalpgâhı olarak isimlendirilen BAE, Suudi Arabistan ve Bahreyn, jeopolitik bir blok hüviyetine sahiptir ve diş politikada çoğu zaman ortak bir tutum sergilemektedirler. Bu bağlamda özellikle de Katar Krizi (2017) esnasında gösterdikleri kolektif performans, söz konusu jeopolitik blok olgusunu da ispatlar mahiyettedir. Son yıllarda İsrail ile İbrahim Anlaşması'nı imzalayarak normalleşme/yakınlaşma süreci yaşayan ve ABD ile astronomik meblağlarla silah alım anlaşmaları imzalayan devletler de yine Arap kalpgâhı olarak isimlendirilen ülkelerdir. Söz konusu politik açılımları ve silahlanma süreçlerini proaktif politika yapım süreçlerinin parçaları olarak görmek gerekmektedir. Kaldı ki Arap kalpgâhını oluşturan devletlerin bir diğer ortak noktasını da son yıllarda Arap dünyasındaki politik trendleri yönlendirme çabası oluşturmaktadır. Bu çerçevede Arap kalpgâhı, bölgesel politikalar açısından bir lokomotif rolü oynamak istemektedir. Elbette ki bir diğer gerekçe ise söz konusu devletlerin son yıllarda özellikle Orta Doğu'da ve Akdeniz'de Türkiye karşıtı politikalar üretmeleri ve takip etmeleridir. Bu bağlamda Arap kalpgâhı olarak isimlendirilen devletler kümesi, Türk büyük stratejisi açısından bir sorun odağı olarak algılanmaktadır.

Arap yarımadasının güney sahillerinde bulunan Yemen ve Umman ise daha ziyade rimland olarak konumlandırılabilir. Bu bağlamda Arap 
kalpgâhı, Yemen ve Umman'dan oluşan güney rimlandin tesiri altındadır. Ayrıca kuzey sahillerini tutan İsrail de Arap kalpgâhının kuzey rimlandini teşkil eder. Kızıldeniz'in ve Basra Körfezi'nin karşı kıyılarında bulunan devletler de sınırlayıcı etkilere sahiptir. Bu çerçevede de Mısır, Sudan, Eritre, Cibuti, Somali ve İran, Arap kalpgâhının imkânlarını/kısıtlarını belirler ve bölgenin denetiminde önemli bir rol üstlenir.

Arap kalpgâhı olarak isimlendirilen bu coğrafya, yirminci yüzyılın mühim gelişmelerinden biri olarak fosil yakıtların ve özellikle petrolün sanayileşmede ve dolayısıyla dünya ekonomisinde oynadığı başat rol sebebiyle, büyük güçlerin yoğun ilgisine mazhar olmuştur. Yer altı kaynakları itibariyle oldukça zengin olan bölge, petrol ve doğal gaz gibi temel enerji kaynaklarının üretimi ve ilgili pazarlara ulaştırılması noktasında da oldukça stratejik bir işlev yüklenmektedir. Bu bağlamda Arap kalpgahı, söz konusu yer altı zenginliklerini diplomatik-ekonomik bir silah olarak kullanmış ve uluslararası politikada dönemsel olarak ağırlık sahibi bir konuma ulaşmıştır.

Arap kalpgâhının uluslararası siyasette ön plana çıktığı tarihler göreceli olarak az olsa da kritik anlarda radikal dönüşümlere sebep olması hasebiyle, önemle belirtilmelidirler. 1969'da Kudüs'teki Mescid-i Aksa'da çıkan yangın ve Arap kalpgâhının buna verdiği reaksiyon, uzun on yıllar boyunca sürecek bir teşkilatlanmayı ve ona eşlik eden ümmetçi bir söylemi beslemiştir. Bu bağlamda İslam Konferansı Örgütü teşkil edilmiş ve Kudüs'teki kutsal mekânların İsrail tahakkümüne maruz kalmaması için siyasi bir çaba gösterilmiştir. ${ }^{7}$

Bir diğer önemli kırılma anı ise 1973'teki OPEC krizidir. Yom Kippur Savaşı esnasında Amerikan güçlerinin İsrail'e yardımcı olmaları sebebiyle Arap kalpgâhı, Batılı devletleri cezalandırabilmek adına petrol üretimlerini düşürmüş ve böylece petrol fiyatlarının astronomik ölçülerde artmasına sebep olmuşlardır. ${ }^{8}$ Petrolün uluslararası politikada bir silah olarak kullanılmasına referans teşkil eden bu örnek, aynı zamanda Batılı devletlerin ekonomilerinin enerji kaynaklarına yoğun bağımlılığını hatırlatmış ve

\footnotetext{
7 Jeff Haynes, "Transnational Religious Actors and International Politics", Third World Quarterly, Vol. 22, No. 2, 2001, 143-158, p. 152-156.

8 Michael L. Dockrill and Michael F. Hopkins, The Cold War, 1945-1991, Palgrave Macmillan; Second Edition, New York, 2006, p. 116.
} 
ilgili devletlerin ekonomik güvenlik sahasındaki tedbirlerine enerji arz güvenliğini de eklemelerine vesile olmuştur. ${ }^{9}$ Böylece OPEC krizi ve dolayısıyla Arap kalpgâhı, uluslararası politikada dönüştürücü bir etki doğurarak, merkezi bir pozisyon elde etmiştir.

Fakat yukarıda anlatılanların istisna olarak kabul edilmeleri durumunda, Arap kalpgâhının modern dönemi esas alındığında genel hatlarıyla dış güçler tarafından şekillendirilmiş ve onlara ram olmuş bir profil gözlemlenebilir. Özellikle Osmanlı İmparatorluğu'nun dağılmasından sonra, bölgede oluşturulan yeni devletler uluslararası politika sahnesinde güçlü ve otonom bir varlık gösterememişlerdir. Arap kalpgâhının devletleri de diş güçlerle ilişkilerini korumak ve güçlendirmek yoluyla, ulusal düzeyde kendi iktidarlarını konsolide etme yoluna gitmişler ve neredeyse devlet ömürleri boyunca ulusal sistemlerinde herhangi bir reforma gitmeksizin hüküm sürmüşlerdir. Günümüzde dahi Arap kalpgâhının temel motivasyonu, arkaik bir nitelik sunan ulusal sistemlerinin hanedan merkezli yapılarına halel gelmesinin önüne geçmektir. Bu durum, rejim güvenliğini başat norm kılarak, büyük güçlerle ilişkilerin istikrarlı bir biçimde yürütülmesine de zemin hazırlamaktadır.

\section{Arap Rimland'ini Tanımlamak}

Nicholas J. Spykman'ın ortaya attığı bir yaklaşım olarak rimland kuramı, Rusya'nın sahip olduğu kalpgâhın denetimini sağlayabilmek amacıyla kurgulanmıştır. Bu çerçevede, daha ziyade bir Soğuk Savaş ürünü olarak rimland, Asya adasını çevreleyen kıyı devletleriyle kurulacak askerî işbirliklerinin doğal bir sonucu olarak Rus gücünün sinırlandırılmasını ve kalpgâhın kontrol edilebilmesini mümkün kılacaktır. ${ }^{10}$ Bu teori, Soğuk Savaş boyunca Amerikan dış politikasının temel jeopolitik yönelimini de oluşturmuştur.

Amerikan dış politikasının Soğuk Savaş boyunca temel hedefi, George Kennan'ın The Long Telegram'ında bahsettiği üzere, SSCB'yi çevrelemek ve

\footnotetext{
${ }^{9}$ Kathleen J. Hancock and Vlado Vivoda, "International Political Economy: A Field Born of the OPEC Crisis returns to its Energy Roots", Energy Research \& Social Science, Vol. 1, (March 2014), 206-216, p. 209.

${ }^{10}$ Spykman'ın fikirlerini detaylandırdığı iki temel eseri için bknz. Nicholas J. Spykman, America's Strategy in World Politics: The United States and the Balance of Power, Harcourt Brece and Company, New York, 1942; Nicholas J. Spykman, The Geography of the Peace, Harcourt Brace and Company, New York, 1944.
} 
İbrahim Anlaşmaları Sonrası Arap Yarımadasının Jeopolitik Analizi ve Türk Büyük Stratejisinin İmkânları/Kısıtları

komünizmin yayılmasının önüne geçebilmekti. ${ }^{11} \mathrm{Bu}$ bağlamda Amerikan gücü, emperyal bir süreklilik arz eden Rus gücünü sınırlandırabilmek için, SSCB'nin yakın çevresinde askerî ittifaklar kurmalıydı. Başta NATO olmak üzere, Bağdat Paktı (CENTO), SEATO, ANZUS gibi uluslararası yapılanmalar, SSCB'nin Avrupa yarımadasından Asya adasının güneydoğu uçlarına değin çevrelenmesini beraberinde getirecekti. ${ }^{12} \mathrm{Bu}$ çevreleme operasyonunun başat amacı, SSCB'nin kıyı devletlerine ve dolayısıyla açı denizlere ulaşımını engellemekti. Bu prensip, tek bir istisna haricinde işlemiştir. SSCB'nin Afganistan işgali (1979) ve açık denizlere çıkabilir bir pozisyona yaklaşması, söz konusu çevreleme operasyonunun aksadığı fakat sonrasında Afgan direnişine verilen Amerikan desteği sayesinde restore edildiği bir süreci işaretlemiştir. ${ }^{13}$

Rimland kuramının Arap yarımadasına uyarlanması çerçevesinde, Arap kalpgâhının güney sahillerinde konumlanan iki devletin de jeopolitik rolleri kritik düzeydedir. Bu bağlamda güney rimland, Yemen ve Umman'dan oluşur ve bu iki devlet, Arap kalpgâhındaki istikrarın ya da istikrarsızlığın temel kaynakları olarak işlev görürler. Bu çerçevede bakıldığında, özellikle Yemen'in Soğuk Savaş ve sonrası dönemde oynadı̆̆ rol göz önünde bulundurulursa, Arap kalpgâhının istikrarındaki payı da rahatlıkla gözlemlenebilir. ${ }^{14}$

Soğuk Savaş'ın sert bir biçimde devam ettiği ve iki süper gücün nükleer bir savaşın eşiğinde dolaştığı bir dönemde Yemen, sıkı iki kutuplu uluslararası sistemin de dolaylı bir yansıması olarak iç savaşa sürüklenmiş ve doğu-batı hattında iki ayrı parçaya bölünerek, fiilen güneyinde ve kuzeyinde iki ayrı otoritenin tesisiyle parçalı bir görünüm arz etmiştir. ${ }^{15}$

\footnotetext{
11 The Charge in the Soviet Union (Kennan) to the Secretary of State, National Security Archive, https://nsarchive2.gwu.edu//coldwar/documents/episode-1/kennan.htm (Erişim Tarihi: 12.02.2021) ${ }^{12}$ Klaus Dodds, Geopolitics: A Very Short Introduction, Oxford University Press, Oxford, 2007, p. 37.

13 Julie Lowenstein, "US Foreign Policy and the Soviet-Afghan War: A Revisionist History”, Harvey M. Applebaum '59 Award, 2016, p. 6, https://elischolar.library.yale.edu/ cgi/viewcontent.cgi?article=1045\&context=applebaum_award (Erişim Tarihi: 12.02.2021)

${ }^{14}$ Yemen, Soğuk Savaş döneminde de Nasır liderliğindeki Mısır açısından önemli bir test işlevi görmüştür. Bu tarihlerden bu yana Arap liderliğinin sınavı olarak görülebilecek olan Yemen, günümüzde de Suudi Arabistan-BAE ikilisi açısından önem taşımaktadır. Lakin Arap kalpgâhının otoriteleri açısından Yemen, kalpgâhın güneybatı sahillerini tutuyor olmasından ötürü, Mısır dış politikasına nazaran, yaşamsal bir nitelik taşımaktadır.

${ }^{15}$ Ginny Hill, Yemen Endures: Civil War, Saudi Adventurism and the Future of Arabia,
} 
Bu bağlamda Arap kalpgâhının güney sahilleri, bütünüyle bir istikrarsızlığa sürüklenerek Suudi Arabistan'ın merkezinde bulunduğu coğrafi alanı da tehdit eder bir hal almıştır. ${ }^{16}$

Yemen iç savaşı süresince Mısır'ın bölgedeki aktivizmi, bu çerçevede oldukça anlamlıdır. 1960'lı yıllarda Cemal Abdülnasır'ın liderliğinde revizyonist ve anti-emperyalist bir çizgi benimseyen Hür Subaylar rejimi, 1955'teki İsrail'in Gazze baskınının bir sonucu olarak Çekoslovakya ile imzaladıkları silah alım anlaşmasından itibaren sosyalist blokla yakınlaşarak kapitalist Batılı eski sömürgecilerini dengelemeye çalışmış ve bu bağlamda da "Batılı ülkelerin bölgesel işbirlikçisi" olarak algıladığ Suudi Arabistan'ı sınırlandırmayı hedeflemiştir. ${ }^{17}$ Mısır yönetimi endişelerinde haklıydı ve özellikle Suudi Arabistan'ın temsil ettiği geleneksel iktidar modeli eliyle Amerikan yönetimi, Arap milliyetçiliğini temsil eden devrimci güçleri çevrelemenin ve sınırlandırmanın peşindeydi. ${ }^{18}$

Söz konusu rekabet, devrimci Mısır ile monarşist Arap kalpgâhını uzun yıllar boyunca karşı karşıya getirmiştir. Mısır'ın Yemen'deki aktivizminin temelinde de Arap kalpgâhında hâkim bulunan monarşist yapılarda devrimci bir süreci tetiklemek bulunmaktadır. ${ }^{19} \mathrm{Bu}$ bağlamda Yemen, hem kutsal kentlerin de bulunduğu Kızıldeniz'in doğu kıyılarındaki Hicaz bölgesine yakınlığı hem de Bab-ül Mendep Boğazı'nın girişini tutabilecek jeostratejik imkânlara sahip olması nedeniyle, Arap kalpgâhının güneybatı sahillerinden taciz edilebilmesine imkân sağlayan jeostratejik bir lokasyona sahiptir. 1960'lı yıllarda Arap dünyasında hâkim olan devrimci-monarşist rekabeti, Arap kalpgâhının zafiyetleriyle anılan bir süreci doğurmuş ve Suudi Arabistan eksenli kalpgâh monarşileri, ancak Altı Gün Savaşı neticesinde Mısır kuvvetleri kesin bir biçimde İsrail kuvvetlerine mağlup oldukları zaman rahatlamış ve ümmetçi bir söylem

\footnotetext{
Oxford University Press, U.S.A., 2017, p. 22.

${ }^{16}$ A.g.e.

17 Joseph Mann, "King Faisal and the Challenge of Nasser's Revolutionary Ideology", Middle Eastern Studies, Vol 48, Iss 5, 2012, 749-764; Ayrıca şu eserde daha da teferruatlı bir çerçeve bulunabilir: Malcolm Kerr, The Arab Cold War 1958-1967, Oxford University Press; Second Edition, 1967.

${ }_{18}$ Detaylı bilgi için bknz. Salim Yaqub, Containing Arab Nationalism: The Eisenhower Doctrine and the Middle East, The University of North Carolina Press, U.S.A., 2004.

${ }^{19}$ Joseph Mann, a.g.e.
} 
İbrahim Anlaşmaları Sonrası Arap Yarımadasının Jeopolitik Analizi ve Türk Büyük Stratejisinin İmkânları/Kısıtları

eşliğinde uluslararası politikada proaktif bir konum edinebilmişlerdir. ${ }^{20}$

2010 yılının son günlerinde patlak veren Arap Baharı de benzer bir jeopolitik sonuca sebebiyet vermiş ve Arap rejimlerindeki halk hareketlerinin domino etkisi Yemen'e de ulaşmış ve Yemen, yine bir iç savaşa zemin olmuştur. Arap Baharı'nın ürettiği jeopolitik rekabet, özellikle bir dış güç olarak İran'ın bölgedeki etkinliğini arttırmış ve Yemen'de de Suudi Arabistan'ın temsil ettiği merkezi tehdit edecek bir konuma ulaşmasına imkân vermiştir. ${ }^{21}$

Suudi Arabistan toprakları, Yemen'deki iç savaş sürecinde defalarca hedef haline gelmiş ve İran destekli Husi milisleri, başta başkent Riyad olmak üzere birçok Suudi kent merkezine saldırılar gerçekleştirebilmişlerdir. ${ }^{22}$ Günümüzün teknolojik imkânları vesilesiyle gelişen hava saldırı araçları, uzun menzilli füzeler ve otonom insansız hava araçları sayesinde İran, Husi milislerinin kullanımına soktuğu imkânlarıyla Suudi Arabistan'ın konvansiyonel ulusal güvenlik algılarını köpürtmüştür. Bu çerçevede Yemen'in Suudi Arabistan açısından önemi, Arap Baharı boyunca da defaatle gözlemlenebilmiştir.

Bu bağlamda yaşananlar, aslında 1960'lı yıllardaki süreçten çok farklı bir içerik sunmamaktadır. 1960'lı yıllarda Mısır'ın devrimci bir retorikle revizyonist amaçlarını projekte ettiği Arap kalpgâhı, 2010’lu yıllar itibariyle yine revizyonist hedeflere sahip İran'ın müdahale ettiği bir coğrafya olarak öne çıkmıştır. Günümüzde Yemen iç savaşı, İran destekli Husi milislerinin özellikle ülkenin Bab-ül Mendep Boğazı'na bakan kıyılarını kontrol ediyor olması hasebiyle, ${ }^{23}$ uluslararası politika

${ }^{20}$ Fawaz A. Gerges, "The Transformation of Arab Politics: Disentangling Myth From Reality”, The 1967 Arab-Israeli War: Origins and Consequences, (Eds. Wm. Roger Louis \& Avi Shlaim), Cambridge University Press, New York, 2012, p. 285-290.

21 "Iran Threatens Arab National Security: Saudi, Yemeni Ministers", Arab News, 10.09.2020, https://www.arabnews.com/node/1732326/middle-east (Erişim Tarihi: 13.02.2021)

22 "Iran-Allied Houthis in Yemen Fire Missiles at Saudi Capital", Reuters, 09.05.2018, https://www.reuters.com/article/us-saudi-security/saudi-arabia-says-it-intercepts-houthimissiles-over-riyadh-idUSKBN1IA100 (Erişim Tarihi: 10.02.2021)

23 Bab-ül Mendep Boğazı'ndaki etkinliğini güçlendirebilmek, Somali ve Cibuti'deki yatırımlarının güvenliğini sağlamak ve Yemen'de mevzi kazanabilmek adına BAE, Sokotra adasında yoğun bir askerî yığınaklanmaya girişmiştir. Bu sebeple adanın BAE tarafindan "işgal edildiğine" yönelik çeşitli söylentiler dahi çıkmıştır. Bknz. Seth J. Frantzman, "Socotra: How a Strategic Island Became Part of a Gulf Power Struggle", The Jerusalem Post, 
açısından da sorunlu bir görünüm sunmaktadır. ${ }^{24}$

Ayrıca Arap kalpgâhının kuzey yönünde Akdeniz'e çıkışı da oldukça sorunludur. Bu noktada da sahil şeridini tutan İsrail, Arap yarımadasının Akdeniz'le ilişkisini tayin edici bir role sahiptir. $\mathrm{Bu}$ bağlamda düşünüldügünde İsrail'in denetim kurduğu coğrafi alan, Arap kalpgâhının denizlere ulaşımını denetleyebilecek bir imkân sunar. Bir başka ifadeyle, Spykman'a referansla söylemek gerekirse İsrail'in hâkimiyet kurduğu coğrafi alan, Arap kalpgâhının rimlandinin denetim altında tutulmasını sağlar.

İsrail'in coğrafi olarak konumlandığı bölgede sahip olduğu jeostratejik imkânlar, Arap yarımadasına uzanabilecek iletişim kapasitesini de belirleyici bir pozisyondadır. Söz gelimi, İsrail'in kuzey bölgesinde konumlanmış Hayfa Limanı, Arap yarımadasına Akdeniz'den açılan bir kapı hüviyeti taşır. Ayrıca söz konusu limanın ticaret hacmi, bölge ülkelerinin dış dünyayla ticari bağlantılarının sürekliliği noktasında da kritik bir profil sunar. ${ }^{25}$

Ayrıca söz konusu liman olanakları, İsrail'i ulaşım hatlarıyla Arap kalpgâhına entegre edecek projelerin de önünü açmıştır. Bu çerçevede, özellikle de demiryolu ulaşımı noktasında yeni projelerin ortaya atıldığını belirtmek gerekmektedir. Hayfa Limanı'na ulaşacak söz konusu demiryolu hatları, Arap kalpgâhının Akdeniz'e ve oradan da dünyanın çeşitli noktalarına erişebilmesini sağlayacaktır. ${ }^{26}$ Söz konusu projelerin altyapısını ise Arap kalpgâhındaki demiryolu projeleri oluşturmaktadır. Bu bağlamda, Arabistan yarımadasının demiryolları inşa edilmek suretiyle jeopolitik bir entegrasyon süreci içerisinde olduğunun altını çizmek gerekmektedir. ${ }^{27}$ Arap kalpgâhını kuzey-güney hattında katedecek demiryolu projeleri,

06.05.2018, https://www.jpost.com/middle-east/socotra-how-a-strategic-island-became-partof-a-gulf-power-struggle-553599 (Erişim Tarihi: 06.07.2021)

${ }^{24}$ Michael Knights and Farzin Nadimi, "Curbing Houthi Attacks on Civilian Ships in the Bab AlMandap", The Washington Institute, 27.07.2018, https://www.washingtoninstitute.org/policyanalysis/curbing-houthi-attacks-civilian-ships-bab-al-mandab (Erişim Tarihi: 10.02.2021)

25 Altay Atl, "China, Israel and the Geopolitics of Seaports", The Diplomat, 16.07.2019, https://thediplomat.com/2019/07/china-israel-and-the-geopolitics-of-seaports/ (Erişim Tarihi: 12.02.2021)

26 "Israel to Begin Promoting Railway Linking Haifa Seaport with Saudi Arabia", The Times of Israel, 24.06.2018, https://www.timesofisrael.com/israel-to-begin-promotingrailway-linking-haifa-seaport-with-saudi-arabia/ (Erişim Tarihi: 12.02.2021)

27 "Ministers Discuss Trans-Gulf Railway Project", Arab News, 25.12.2020, https://www.arabnews.com/node/1782521/saudi-arabia (Erişim Tarihi: 12.02.2021) 
İbrahim Anlaşmaları Sonrası Arap Yarımadasının Jeopolitik Analizi ve Türk Büyük Stratejisinin İmkânları/Kısıtları

gerçekleşmeleri halinde İsrail'in rimland statüsünü vazgeçilemez bir konuma ulaştıracaktır.

İsrail'in rimland statüsünü perçinleyebilecek bir başka gelişme ise Eilat-Aşkelon arasındaki boru hattının ${ }^{28}$ Suudi Arabistan'a uzatılması yönündeki projelerdir. Bu bağlamda, Suudi Arabistan'ın Medine kenti kıyılarında bulunan Yenbu kentine kadar uzatılması planlanan boru hatt1, hem enerji talebindeki ülkeler açısından maliyetleri düşürecek hem de Süveyş Kanalı ve Bab-ül Mendep Boğazı üzerinden gelişebilecek potansiyel istikrarsızlıkları ve dolayısıyla enerji arz güvenliğine yönelebilecek tehditleri elimine etmeye yarayacaktır. ${ }^{29} \mathrm{Bu}$ çerçevede düşünüldüğünde, Suudi Arabistan'ın uluslararası piyasalara optimum yollarla enerji arzı sağladı̆̆ güzergâhta bir hegemonya tesis edecek olan İsrail, Arap kalpgâhı açısından stratejik bir konuma ulaşacaktır. Kuzey rimlandin bu statüsü, Arap kalpgâhının jeostratejik imkânlarını arttırmakla birlikte, coğrafyanın dayattığı şartlar doğrultusunda bir tür bölgeselleşmeyi de zorunlu hale getirecektir.

\section{Denizler, Boğazlar, Kanallar ve Arap Kalpgâhının Kontrolü}

Klasik jeopolitiğin önemli temsilcilerinden Alfred Thayer Mahan'ın da kuramsallaştırdığı çerçevede suyolları ve boğazlar, ilgili coğrafyada hâkimiyet tesis edilebilmesi aşamasında başat bir rol oynamaktadır. $\mathrm{Bu}$ çerçevede büyük güçler, Mahan'ın telkinleri doğrultusunda, dünya hâkimiyetini elde etmek arzusunda iseler suyollarını ve boğazları denetim altında tutmak zorundadırlar. Böylesi bir denetim mekanizması, Britanya İmparatorluğu'nun on sekizinci yüzyıl itibariyle elde ettiği denizlerdeki

\footnotetext{
${ }^{28}$ Söz konusu boru hattı üzerinden BAE'nin petrol sevkiyatını gerçekleştirme hedefi ve bu çerçevede yapılan anlaşmalar da İsrail'in rimland statüsünü perçinlemek adına ayrıca değerlidir. Böylece BAE petrolü, Süveyş Kanalı'na alternatif bir rota takip ederek, Avrupa piyasalarına İsrail üzerinden ulaștırılmıș olmaktadır. Detaylı bilgi için bknz. Ari Rabinovitch, Tova Cohen, "Israeli Pipeline Company Signs Deal to Bring UAE Oil to Europe", Reuters, 20.10.2020, https://www.reuters.com/article/us-emirates-israel-pipeline/israeli-pipeline-company-signs-dealto-bring-uae-oil-to-europe-idINKBN275155 (Erişim Tarihi: 06.07.2021)

Ayrıca bu gelişme, Süveyş Kanalı'nı göreceli olarak önemsizleştireceği için Mısır nezdinde tepkiye yol açmıştır. Bknz. Khalid Hassan, “"Egypt Concerned UAE-Israeli Pipeline Project will Affect Suez Canal", Al Monitor, 08.02.2021, https://www.al-monitor.com/originals/2021/02/ egypt-israel-uae-ashkelon-eilat-oil-pipeline-suez-canal.html (Erişim Tarihi: 06.07.2021)

29 Amiram Barkat, "Israel to Propose Saudi-Israel Oil Pipeline", Globes, 16.09.2020, https://en.globes.co.il/en/article-israel-to-propose-saudi-israel-oil-pipeline-1001343034

(Erişim Tarihi: 15.02.2021)
} 
hâkimiyetine referansla, uluslararası ticaretin ve dolayısıyla sermaye birikiminin imkânlarını da genişletecektir. Mahan'ın Amerikan yönetimine tavsiyeleri de bizatihi Hollanda ve Britanya İmparatorluğu'nun denizlerdeki tarihine yönelik jeopolitik ve analitik çıkarımların bir bütününü temsil etmektedir. $^{30}$

Amerikan gücü de uluslararası hukukun oluşumu ve kurumsallaşması açısından henüz erken bir tarih olarak görülebilecek bir dönemde, Başkan Wilson'ın Birinci Dünya Savaşı esnasında açıklamış olduğu prensiplere denizlerin serbestîsini ekleyerek söz konusu amaca doğru bir adım atmıştır. Son olarak 1982'de imzaya açılan BM Deniz Hukuku Sözleşmesi de söz konusu liberal hegemonyanın tesisi açısından kritik önemdeki denizlerin serbestîsi ilkesini hukukileştirerek çağdaş deniz jeopolitiğinin önemli bir parçası haline getirmiştir. ${ }^{31}$

Mahan'ın denizlerde hâkimiyet tesis edilebilmesi için önerdikleri göz önünde bulundurulursa yeni bir ölçeklendirmeyle, Arap yarımadasını çevreleyen denizleri, boğazları ve kanalları Arap yarımadasını kontrol edebilmek adına incelemek ve analitik bir anlamlandırmaya tabi kılmak gerekmektedir. $\mathrm{Bu}$ bağlamda Arap kanalları olarak kabul edilebilecek biricik oluşum, Mısır'ın ${ }^{32}$ toprakları içerisinde bulunan Süveyş Kanalı'dır.

\footnotetext{
${ }^{30}$ Mahan'ın söz konusu fikirlerini kaleme aldığı eser için bknz. Alfred Thayer Mahan, The Influence of Sea Power Upon History, 1660-1783, Cambridge University Press, Cambridge, 2011. ${ }^{31}$ Part III, "Straits Used for International Navigation", United Nations Convention on the Law of the Sea, Nova Science Publishers, New York, 2009, p. 17-23.

${ }^{32}$ Misır, karasal bir devamlılık eseri, Arap rimlandine dâhil edilebilir. Lakin Arap kalpgâhıyla direkt bir bağlantısı olmaması ve ancak Ürdün ve İsrail toprakları katedilerek ulaşılabilir olması, farklı bir konum edinmesine sebep olur. Yakın tarihlerde Suudi Arabistan'ın açıkladığı, Tiran ve Sanafir Adaları üzerinden geçerek Sina Yarımadası'na ulaşacak karayolu projeleri, özellikle bu bölgeyi bir rimland alanına dönüştürebilir. Fakat Sina Yarımadası'nın Misır anakarasıyla arasında Süveyş Kanalı bulunmaktadır ve bu kopukluk, bizatihi Yom Kippur Savaşı'nda jeostratejik bir açık olarak tecrübe edilmiştir. Ayrıca Sina Yarımadası'nın uzun bir kıyı hattına sahip olması fakat herhangi bir liman olanağına sahip olmaması sebebiyle, anlamlı bir sonuca ulaşmamaktadır. Bir başka boyutuyla da Sina Yarımadası, 1978-79 yıllarında Camp David Anlaşması'yla kurulan statü sebebiyle, askerden arındırılmış ve bölge, Mısır merkezi otoritesinin kontrolünden kısmen çıkmıştır. Yukarıda anılanlar çerçevesinde düşünüldüğünde Mısır'ın Süveyş Kanalı üzerindeki yetkileriyle sınırlı bir jeopolitik değeri olduğu sonucuna ulaşılabilir. Ayrıca Mısır, Arap kalpgâhına denizden komşu olması hasebiyle, Kızıldeniz kıyılarındaki istikrar açısından kritik düzeyde önemli bir jeopolitik aktördür.
} 
İbrahim Anlaşmaları Sonrası Arap Yarımadasının Jeopolitik Analizi ve Türk Büyük Stratejisinin İmkânları/Kısıtları

Süveyş Kanalı, 1869 yılında İngilizlerin Hint sömürgelerine ulaşmalarını kolaylaştırabilmek ve Afrika kıtasının güney ucu olan Ümit Burnu'ndan dolaşan güzergâha alternatif üreterek ulaşım maliyetlerini düşürebilmek amaciyla inşa edilmiş ve bu tarihten itibaren de jeostratejik ve jeopolitik önemini çeşitli seviyelerde muhafaza edebilmiştir. ${ }^{33}$ Fakat günümüzde Süveyş Kanalı'na alternatif yapıların gündeme gelmesi, Suudi Arabistan merkezli bir jeopolitik atılımın da mihenk taşını simgelemektedir. $\mathrm{Bu}$ bağlamda, kuzey rimlandin dominant gücü olarak İsrail'le BAE aracılığıyla yapılan görüşmeler, Suudi otoritesinin Süveyş Kanalı'na alternatif bir su geçiş yolunun inşa edilmesine verdiği önemi göstermektedir. ${ }^{34}$

Söz konusu alternatif projeler, Süveyş Kanalı sayesinde Mısır'ın elde ettiği hegemonik konumunu ortadan kaldırmayı hedeflemektedir. Kızıldeniz'in kuzey ucundan Akdeniz'e çıkışı sağlayan hâlihazırdaki biricik güzergâh olan Süveyş Kanalı, Akabe Körfezi'nde bulunan İsrail'in Eilat kentinden başlayacak ve Doğu Akdeniz limanlarından Aşdod'a uzanacak bir kanal inşaatıyla ortaya çıkacak alternatif bir ulaşım kapasitesiyle $\mathrm{e}^{35}$ önemini yitirebilecektir. ${ }^{36} \mathrm{Bu}$ çerçevede düşünüldüğünde, Suudi Arabistan Veliaht Prensi Muhammed Bin Selman'ın (MbS) vizyon

\footnotetext{
33 Süveyş Kanalı'nın jeostratejik önemi, 2021 yılının Mart ayı sonlarında yaşanan bir krizle yeniden tescillenmiştir. Evergreen isimli yük gemisinin kontrolünü kaybederek kanalın içerisinde karaya oturması, uluslararası ticaretin günlerce aksamasına ve başta Mısır yönetimi olmak üzere pek çok tarafin ekonomik zarara uğramasına sebep olmuştur. Bknz. "Egypt's Suez Canal Blocked by Huge Container Ship", BBC, 24.03.2021, https://www.bbc.com/ news/world-middleeast-56505413 (Erişim Tarihi: 07.07.2021)

34 “Egypt Vexed By Israel, UAE Plans for 'Rival Suez Canal'”, The New Arab, 02.10.2020, https://english.alaraby.co.uk/english/news/2020/10/2/egypt-vexed-by-israeli-emirati-plansfor-rival-suez-canal (Erişim Tarihi: 14.02.2021)

${ }^{35}$ Söz konusu alternatif kanal projelerinin tarihi, son aylarda ortaya çıkan bilgilerle birlikte, onyıllarca geriye götürülebilmektedir. Buna göre, Amerikan yönetimi tarafindan 1963 yılında hazırlanmış bir planda, İsrail üzerinden Akdeniz'i Akabe Körfezi'ne bağlayacak bir kanal projesi gündeme gelmiştir. Bahsi geçen planın belki de en ilginç özelliği ise kanal açma çalışmalarını nükleer bombalarla gerçekleştirmeyi hesaplamasıdır. Bu tarihlerde söz konusu kanal projesi hayata geçirilememiştir. Detaylı bilgi için bknz. Marianne Guenot, "The U.S. had a Plan in the 1960s to Blast an Alternative Suez Canal through Israel using 520 Nuclear Bombs", Business Insider, 25.03.2021, https://www.businessinsider.com/us-planned-suezcanal-alternative-israel-blast-with-nuclear-bombs-1960s-2021-3 (Erişim tarihi: 06.07.2021)

36 "Egypt Vexed By Israel, UAE Plans for 'Rival Suez Canal"”, The New Arab, 02.10.2020, https://english.alaraby.co.uk/english/news/2020/10/2/egypt-vexed-by-israeli-emirati-plans-

for-rival-suez-canal (Erişim Tarihi: 14.02.2021)
} 
projesi olarak takdim ettiği NEOM kentinin lokasyonu da anlam kazanmaktadır. Akabe Körfezi'ne bakan kıyılarıyla NEOM, Suudi anakarasının dış dünyaya açılan penceresi olarak işlev yüklenmektedir. ${ }^{37}$ Lakin Süveyş Kanalı'nın pasivize edilmesi, beraberinde İsrail namına hegemonik bir statü yaratacak ve Arap kalpgâhı, Akdeniz'e çıkabilmek için İsrail ile istikrarlı ilişkiler kurmak durumunda olacaktır. ${ }^{38}$

$\mathrm{Bu}$ aşamada bir hususu özellikle açıklamak gerekmektedir. Tiran Boğazı ve boğazın güney girişinde bulunan Tiran ve Sanafir adaları, söz konusu kanal projesinin jeopolitik altyapısını oluşturması hasebiyle ayrıca değerlendirilmeye muhtaçtır. 2017 yılında Mısır yönetiminin girişimiyle Suudi Arabistan'a devredilen Tiran ve Sanafir adaları, Tiran Boğazı'nda seyrüsefer serbestîsinin garanti altına alınması noktasında önemli bir rol oynamışlardır. $\mathrm{Bu}$ çerçevede, 1950'li yılların başından itibaren Mısır egemenliğinde bulunan adalar, Tiran Boğazı'nın ve dolayısıyla Akabe Körfezi'nin ve bu körfeze kıyıdaş olan İsrail, Ürdün ve Suudi Arabistan'ın Kızıldeniz doğrultusundaki kapasitesini belirleyici ve denetleyici bir etki yaratmaktaydı. Fakat Suudi Arabistan'a devredilen adalarla birlikte Misır'ın Tiran Boğazı ve Akabe Körfezi üzerinde herhangi bir nüfuzu kalmamıştır. ${ }^{39}$ Hatta denilebilir ki Süveyş Kanalı'na alternatif olarak düşünülen olası EilatAşdod kanalının zeminini söz konusu adaların devri mümkün kılmıştır.

Ayrıca söz konusu Tiran Boğazı, yakın Orta Doğu tarihinde kritik bir pozisyona da sahip olmuş ve hatta 1956'daki Süveyş Krizi ile 1967'deki Altı Gün Savaşı'nın da temel nedenlerinden biri olarak belirmiştir. Bu çerçevede bakıldığında, bahsi geçen tarihlerde Mısır'ın egemenliği altında bulunan Tiran ve Sanafir adaları, Tiran Boğazı'nın girişini kapatabilmek

\footnotetext{
${ }^{37}$ Mohammed Alkhereiji, "Saudi Arabia Embraces a Different Future with NEOM", The Arab Weekly, 23.02.2020, https://thearabweekly.com/saudi-arabia-embraces-differentfuture-neom (Erișim Tarihi: 13.02.2021)

38 "Can MBS's Neom Translate into the Saudi Forging Ties with Israel?", TRT World, 17.08.2020, https://www.trtworld.com/magazine/can-mbs-s-neom-translate-into-the-saudisforging-ties-with-israel-38974 (Erişim Tarihi: 13.02.2021)

${ }_{39}$ Buna rağmen Mısır, Kızıldeniz kıyılarına kurduğu yeni deniz üssü sayesinde bölgesel nüfuzunu arttırıcı birtakım girişimlerde de bulunmaktadır. Detaylı bilgi için bknz. "New Naval Base Boosts Egypt Presence in the Red Sea", The Arab Weekly, 19.01.2020, https://thearabweekly.com/new-naval-base-boosts-egypts-presence-red-sea (Erişim Tarihi: 06.07.2021)
} 
noktasında işlevselleştirilmiş ve İsrail'e gidebilecek deniz nakliye araçları bu yolla engellenebilmiştir. ${ }^{40}$ Mısır'ın İsrail'e uyguladığı söz konusu abluka, daha sonrasında İsrail'in Sina Yarımadası'nı işgal etmesiyle sonuçlanacak Altı Gün Savaşı'nı tetiklemiş ve ancak bu yolla İsrail, ablukayı kırabilmiştir. Bölgenin jeostratejik önemi dolayısıyla İsrail, söz konusu ablukaya benzer bir girişimle bir daha karşılaşmamak amacıyla, Sina yarımadasının Tiran Boğazı'na bakan kıyılarını uzun yıllar boyunca işgali altında tutmuştur. ${ }^{41}$

Kızıldeniz'in doğu yakasında hâkim konumda bulunan Suudi Arabistan'ın açık denizlere ulaşabilmek için iki ayrı güzergâhı kullanabilmesi mümkündür. Bunlar da sırasıyla; Kızıldeniz ve Basra Körfezi'dir. Fakat her iki deniz alanının da karşı kıyılarında hâkim bulunan güçlerin barışçıl bir pozisyon belirlemeleri, bu güzergâhların kullanımı noktasında olmazsa olmaz bir koşuldur. Daha kurumsal bir çerçevedeki gerekli zemin ise temelinde liberal uluslararası düzenin bulunduğu uluslararası hukuk kısıtlamalarının caydırıcılık kapasitesini korumasıdır. Aksi hallerde Arap kalpgâhının dış dünyayla iletişimi kesilebilir.

Öncelikle Basra Körfezi açısından konuya yaklaşıldı̆̆ında karşılaşılan sonuç, oldukça kırılgan bir yapının varlığıdır. Körfezin karşı kıyılarını tutan İran, hem devrimci retoriğiyle hem de Şiicilik üzerine inşa ettiği mezhepçi dış politika vizyonuyla Suudi Arabistan'ın temsil ettiği kalpgâh gücünü sınırlandırmayı hedeflemektedir. ${ }^{42} \mathrm{Bu}$ çerçevede Basra Körfezi, her ne kadar Arap yarımadasının güneydoğu ucunda ve Basra Körfezi'nin çıkışında konumlanan pasifist bir krallığın varlığı söz konusu olsa da İran'ın revizyonist hamle potansiyeli, bölgenin istikrarsız bir çıkış yolu olduğuna işaret etmektedir. Özellikle Irak'ın Kuveyt'i işgali (1990) sürecinde bölgeye konuşlanan Amerikan askerî varlığı çekildiği takdirde, hali hazırdaki status quo hızlı bir biçimde bozulabilir ve İran'ın hegemonik bir yaklaşımla Hürmüz Boğazı'ndan sağlanan deniz geçişlerini kısıtlaması

${ }^{40}$ Eitan Barak, "Between Reality and Secrecy: Israel's Freedom of Navigation Through the Straits of Tiran, 1956-1967", Middle East Journal, Vol. 61, No. 4, (Autumn, 2007), 657679, p. 657-679.

${ }^{41}$ A.g.e.

42 Patrick Van Der Heiden and Alex Krijger, "The Saudi-Iranian Rivalry: An Ominous ZeroSum Game for Supremacy”, Atlantisch Perspectief, Vol. 42, No. 2, 2018, 11-15, p. 11-15. 
mümkün olabilir. ${ }^{43}$

Kızıldeniz'in batı kıyılarında bulunan Mısır, Sudan, Eritre, Cibuti ve Somali, bölgenin istikrarlı bir geçiş güzergâhı olarak kullanılabilmesi için kontrol altında tutulması gereken devletlerdir. Bu çerçeveden bakıldığında, bahsi geçen devletlerden hiçbirinin Arap kalpgâhını temsil eden güçlerin savundukları politik iddialara alternatif bir pozisyon benimsemedikleri görülebilir. $\mathrm{Bu}$ bölgenin istikrarlı bir biçimde Arap kalpgâhını desteklemesi veya en azından uyumlu bir profil sunması, Suudi Arabistan'ın bölgesel güç projeksiyonunun limitlerini belirlemesi açısından, oldukça kritik önemdedir. ${ }^{44}$ Ayrıca bu husus, Kızıldeniz hattı boyunca seyrüsefer güvenliğinin sağlanabilmesi açısından da kritik önemdedir.

Bir başka kritik önemdeki husus olarak, söz konusu denizlerden açık denizlere çıkma zeminini sunan iki önemli deniz geçişinin de Arap kalpgâhının imkânlarını belirleyebilecek kapasitede olmasıdır. Bu bağlamda, Bab-ül Mendep Boğazı ve Hürmüz Boğazı, sırasıyla Arap kalpgâhının güneybatı ve güneydoğu uçlarından kontrol edilebilmesini sağlamaktadır. Arap kalpgâhında istikrarlı bir yönetimin var olabilmesi söz konusu suyollarının istikrarlı bir biçimde açık tutulabilmesinden geçmektedir. ${ }^{45}$ $\mathrm{Bu}$ bağlamda düşünüldüğünde, her iki boğaz da Arap yarımadasının istikrarına derinden tesir edebilecek kapasitedeki coğrafi oluşumlardır.

Ek olarak belirtmek gerekirse, Kizıldeniz'in güney girişinde konumlanmış olan Bab-ül Mendep Boğazı'nın ve Aden Körfezi'nin kıyılarında yaşanan güç boşluğu ve hatta bu coğrafyadaki devletlerin bir

\footnotetext{
43 İran, uzun yıllardır bu konuda tehdit edici açıklamalar yapmaktadır. Hürmüz Boğazı'nı kapatmaya yönelik bir içerikle İran tehditleri, elbette ki bu güzergâhı kullanan devletleri ve onların ticaret hacmini hedef almaktadır. Ayrıca boğazın kapatılmasına yönelik tehditlerini mütemadiyen dile getirmekle birlikte, esas olarak bölgedeki devletlerin deniz araçlarına yönelik birtakım taciz edici politikalarına da devam etmektedir. Söz konusu tehditlere bir örnek için bknz. Ali H. M. Abo Rezeg, "Iran Renews Threat to Close Strategic Strait of Hormuz", Anadolu Agency, 22.04.2019, https://www.aa.com.tr/en/americas/iran-renewsthreat-to-close-strategic-strait-of-hormuz/1460108 (Erişim Tarihi: 12.02.2021)

44 Viola Fahmy, "Arab-African Alliance Announced in Riyadh", Anadolu Agency, 06.01.2020, https://www.aa.com.tr/en/middle-east/arab-african-alliance-announced-in-riyadh/ 1694211 (Erişim Tarihi: 10.02.2021)

${ }^{45}$ Anthony H. Cordesman, "America, Saudi Arabia, and the Strategic Importance of Yemen", Center for Strategic and International Studies, 26.03.2015, https://www.csis.org/analysis/ america-saudi-arabia-and-strategic-importance-yemen (Erişim Tarihi: 08.02.2021)
} 


\section{İbrahim Anlaşmaları Sonrası Arap Yarımadasının Jeopolitik Analizi} ve Türk Büyük Stratejisinin İmkânları/Kısıtları

kısmının başarısız devlet statüsünde olması, yirmi birinci yüzyılda önemli bir jeopolitik risk unsuru olarak belirmektedir. ${ }^{46}$ Söz konusu güç boşluğundan semizlenen korsanlık faaliyetleri, uluslararası ticaretin istikrarlı bir biçimde devam edebilmesinin de önündeki en büyük engellerden birisidir. Bu bağlamda, Somali açıklarında sıklıkla görülen korsanlık faaliyetlerini engelleyebilmek adına uluslararası toplum da harekete geçmiş ve NATO kapsamında Türkiye'nin de parçası olduğu çeşitli düzeylerde operasyonlar icra edilmiştir. ${ }^{47}$

Söz konusu jeopolitik riskin temelinde, boğaz bölgesinde hâkim bir gücün bulunmaması yatmaktadır. ${ }^{48} \mathrm{Bu}$ durum, bölgeye yönelik nüfuz politikaları güden devletler için bir avantaj olarak görülebilecekse de kısa ve orta vadede bölgenin ve dolayısıyla Arap kalpgâhının istikrarsızlaştırılması için uygun bir zemin oluşturmaktadır.

Yukarıda anıldığı ölçülerde, hem Bab-ül Mendep Boğazı hem de Hürmüz Boğazı'nın kıyıdaş ülkelerindeki politik uyum, Arap kalpgâhındaki otoritenin istikrarı açısından elzemdir. İsimlendirmek gerekirse Bab-ül Mendep Boğazı'nda Cibuti, Somali ve Yemen; Hürmüz Boğazı'nda ise İran ve Umman'la uyumlu politik ilişkiler, Arap kalpgâhının istikrarına yönelik başat koşullardır. Söz konusu boğazlar transit geçişe açık oldukları müddetçe Arap kalpgâhındaki otoritenin açık denizlere çıkma ihtimali mümkün olacaktır. Aksi halde Arap yarımadası, söz konusu jeostratejik suyollarının yaratabileceği olumsuzluklarla baş etmek zorunda kalacaktır.

$\mathrm{Bu}$ bağlamda belirtmek gerekir ki özellikle Umman Krallığı, uluslararası ve bölgesel politikada tarafsılık eksenli bir çizgi izleyerek,

\footnotetext{
${ }^{46}$ Lupus De Bello, "Kenya is Somalia's Latest Victim in Region of Failed States", The Conversation, 24.09.2013, https://theconversation.com/kenya-is-somalias-latest-victim-inregion-of-failed-states-18582 (Erișim Tarihi: 11.02.2021)

47 "Operation Ocean Shield", NATO, https://mc.nato.int/missions/operation-ocean-shield (Erişim Tarihi: 13.02.2021)

48 Son yıllarda yaşanan jeopolitik rekabetin yansımaları özellikle de Kızıldeniz'in güney çıkışında yoğunlaşmaktadır. $\mathrm{Bu}$ çerçevede BAE de Yemen'deki istikrarsızlıktan faydalanarak, ülkenin Bab-ül Mendep boğazını denetim altına almayı kolaylaştırabilecek olan Perim adasına bir hava üssü kurmaktadır. İsrail istihbaratına yakınlığıyla bilinen DEBKA sitesinin haberi bu bağlamda önemlidir. Detaylı bilgi için bknz. "The UAE is Building a New Airbase off Yemen to Control and Safeguard Red Sea Shipping", DEBKA, 28.05.2021, https://www.debka.com/the-uae-is-building-a-new-airbase-off-yemen-to-control-and -safeguard-red-sea-shipping/ (Erişim Tarihi: 07.07.2021)
} 
söz konusu jeostratejik önemini korumaya ve işlevselleştirmeye gayret etmektedir. ${ }^{49}$ Kaldı ki bahsi geçen coğrafyadaki olası istikrarsızlıklar, direkt olarak Arap kalpgâhını etkisi altına alacak ve dış dünyayla olan bağlantısını önemli oranda kısıtlayabilecektir. Bu çerçevede Umman'ın takip ettiği dış politika, halihazırda Arap kalpgâhı açısından optimum seçeneği sunmaktadır.

\section{Türk Büyük Stratejisinin İmkânları/Kısıtları}

Yukarıda da anıldı̆̆ yana yaşanan sistemik ve bölgesel dönüşümler, Arap jeopolitiğini yeniden şekillendirmek ve anlamlandırmak noktasında önem arz etmekle birlikte, Türk stratejisinin bölgesel ölçekli yaklaşımını da gözden geçirmesini dayatmaktadır. Bu bağlamda Türk stratejisi, yukarıda etraflıca ele alınan Arap jeopolitiğinin hassas noktalarında etkin bir pozisyon benimseyerek, ilgili devletlere kendi ulusal çıkarları doğrultusunda fonksiyonlar yükleyebilir.

Son yıllarda ve özellikle Arap Baharı'nın yarattığı fırsatlara istinaden Türkiye, bölgesel görünürlügünü ve varlığını güçlü bir biçimde arttırmış ve kamuoyunca "Türk üçgeni” olarak bilinen bir çevreleme eylemini hayata geçirmiştir. ${ }^{50}$ Söz konusu kavramsal önerme, Türkiye'nin Katar, Somali ve Sudan'da elde ettiği askerî imkânlar dolayısıyla kurgulanmıştır. Bu çerçevede Türkiye, Arap kalpgâhı açısından bakıldığında, hem Sudan'la anlaşarak Kızıldeniz'in batı yakasında pozisyon almış hem Somali'deki askerî varlığıyla Bab-ül Mendep Boğazı'nı denetleyebilecek bir imkâna kavuşmuş hem de Katar'da bulundurduğu askerî birlikler vasıtasıyla da Basra Körfezi'nde bayrak gösterebilir bir statüye ulaşmıştır. Bu bağlamda, “Türk üçgeni” olarak bilinen askerî varlıklar, Arap kalpgâhını çevreleyen ve bir dereceye kadar kontrol edebilecek bir kapasiteye sahip olarak görülebilir.

Fakat ilerleyen tarihlerde yaşanan bazı bölgesel gelişmeler, söz konusu statüyü de tartışmalı bir hale sokmuştur. Bu açıdan bakıldığında,

\footnotetext{
49 Umman Sultanlığı’nın dış politikadaki özgün duruşunu tarihsel bir bağlam içerisinde açıklayan önemli bir çalışma için bknz. Joseph A. Kechichian, Oman and the World: The Emergence of an Independent Foreign Policy, RAND, Santa Monica, 1995.

50 "Son Hamlenin Ardından Ortaya Çıktı! İşte Türk Üçgeni...”, Milliyet, 27.12.2017, https://www.milliyet.com.tr/gundem/son-hamlenin-ardindan-ortaya-cikti-iste-turk-ucgeni2580269 (Erişim Tarihi: 14.02.2021)
} 
İbrahim Anlaşmaları Sonrası Arap Yarımadasının Jeopolitik Analizi ve Türk Büyük Stratejisinin İmkânları/Kısıtları

özellikle Sudan'da gerçekleştirilen askerî darbe ve Ömer El-Beşir yönetiminin devrilerek, yerine General Burhan yönetiminin tesis edilmesi, "Türk üçgeninin" Kızıldeniz ayağını sakatlamıştır. General Burhan'ın yaptı̆̆ açılamalar, Türkiye-Sudan arasında anlaşmaya varılan Sevakin adasının kiralanmasının askerî bir içerikte olmadığını iddia etmektedir. Buna göre, Sevakin adasındaki Osmanlı İmparatorluğu döneminden kalma saray restore edilecek ve turistik faaliyetler doğrultusunda kullanılacaktır. ${ }^{51} \mathrm{Bu}$ gelişmeye istinaden denilebilir ki genelde Kızıldeniz ve özelde Sudan'daki Türk varlığı, devrik lider Beşir yönetiminde potansiyel bir varlık gösterebilecekken General Burhan yönetimindeki Sudan'1, bölgesel güç projeksiyonu açısından bir sütun olarak kullanamayacaktır. Burhan'ın yapmış olduğu açıklamalarda Kızıldeniz'in karşı kıyısındaki Suudi Arabistan'ın çekincelerine de atıf yapması Burhan yönetiminin Arap kalpgâhını rahatsız edebilecek herhangi bir sürecin parçası olmamaya dikkat ettiğini de göstermektedir. Bu çerçevede, yukarıda da anlatıldığı üzere Arap kalpgâhının, Kızıldeniz üzerinden gelebilecek istikrarsızlaştırıcı eylemleri, bölgede bulunan devletlerin militarist yönetim elitlerini destekleyerek engellemeye çalıştığı ve ulusal güvenliğini bu doğrultuda konsolide ettiği söylenebilir. ${ }^{52}$

Türk büyük stratejisi açısından Arap kalpgâhının geleceği; politik yönelimleri ve istikrarı ölçüsünde kritik bir önemdedir. Yukarıda anılan askerî güvenlik ve denetim imkânlarına ek olarak, Türkiye'nin Arap kalpgâhıyla ticaret hacmi, olası bir istikrarsızlık halinde ekonomik güvenliğini tehlikeye atabilecek boyutlardadır..$^{53} \mathrm{Bu}$ bağlamda bakıldığında,

\footnotetext{
51 Yaşar Yakış, "How the Khartoum Coup will Affect Turkey-Sudan Relations", Arab News, 21.04.2019, https://www.arabnews.com/node/1485706 (Erişim Tarihi: 14.02.2021)

${ }^{52} \mathrm{Bu}$ bağlamda, Sudan ve Mısır'daki askerî darbe süreçlerine verilen destek, jeopolitik ve jeostratejik bir ihtiyaç olarak, Kızıldeniz'in karşı kıyısında kontrol edilebilir ve istikrarlı yönetimlerin bulunmasının tercih edildiğine oldukça berrak bir biçimde işaret etmektedir. İlgili haberler için bknz. Declan Walsh, "Amid U.S. Silence, Gulf Nations Back the Military in Sudan's Revolution", The New York Times, 26.04.2019, https:/www.nytimes.com/2019/04/ 26/world/africa/sudan-revolution-protest-saudi-arabia-gulf.html (Erişim Tarihi: 05.02.2021); Rod Nordland, "Saudi Arabia Promises to Aid Egypt's Regime", The New York Times, 19.08.2013, https://www.nytimes.com/2013/08/20/world/middleeast/saudi-arabia-vows-toback-egypts-rulers.html (Erişim Tarihi: 06.02.2021)

53 Katar Krizi'nin patlak verdiği ve Türkiye-Katar ikilisinin Arap kalpgâhıyla karşıt pozisyonları temsil ettiği 2017 yılında bile Türkiye'nin bölgeyle ticaret hacmi, yaklaşık
} 
Arap kalpgâhının kuzey rimland alanından Akdeniz'e açılma pratiğini hayata geçiriyor olması Türk büyük stratejisi açısından üzerinde özellikle düşünülmesi gereken bir meseledir. Arap kalpgâhının Akdeniz'e çıkışını sağlayan İsrail, uzun yıllardır Türkiye ile istikrarlı bir ilişkiye sahip değildir. $\mathrm{Bu}$ çerçevede düşünüldüğünde, şayet bahsi geçen ulaştırma projeleri hayata geçirilirse, Arap kalpgâhı İsrail'e sıkı sıkıya bağlı bir hale gelecektir. Bu durum da beraberinde, Suriye'deki iç savaş ortamı ve Irak'taki istikrarsız atmosfer de göz önünde bulundurulduğunda, Türkiye'nin Arap kalpgâhına ulaşabilmek için İsrail güzergâhından başka seçeneğinin kalmamasına sebep olacaktır.

2017 yılında gelişen Katar ablukası süreci de bu bağlamda oldukça öğreticidir. Türkiye-Katar ilişkilerinin özellikle Arap Baharı sürecinde farklı bir safhaya geçmesi, her iki devletin de muhalif hareketleri destekleyici ve Arap dünyasındaki dönüşümü onaylayıcı tutumları, bölgesel düzeyde monarşist ve status quo yanlılarının tepkilerini çekmiştir. Bu çerçevede, Arap kalpgahı tarafindan Haziran 2017 itibariyle Katar'a uygulanmaya başlanan ablukanın kaldırılması için öne sürülen koşullar arasında, Türkiye'nin bölgedeki askerî varlığı da hedef alınmıştır. ${ }^{54}$ Katar'daki Türk üssü, bu süreç boyunca yerleşik yönetici elitin temel dayanaklarından birisi olmuş ve askerî bir darbe ihtimalini de engellemiştir. Bu bağlamda, Katar'daki Türk askerî varlığı kazanılmış önemli bir pozisyon olarak düşünülmeli ve korunmalıdır.

Sistemik güç dağılımlarındaki dönüşüme rağmen Arap kalpgâhının son yıllardaki temel yöneliminin Amerikan eksenli bir seyir izlemesi, bunu da İsrail'le jeopolitik ve jeostratejik entegrasyona giderek yapıyor olması

olarak 56,4 milyar dolardır. İlgili haber için bknz. "Türkiye, Ortadoğu ve Körfez Ülkeleriyle İşbirliğini Büyütüyor”, TRT Haber, 27.04.2018, https://www.trthaber.com/haber/ekonomi/ turkiye-ortadogu-ve-korfez-ulkeleriyle-ticaretini-buyutuyor-362796.html\#: :text=T\%C3\%

BCrkiye'nin\%20Ortado\%C4\%9Fu\%20ve\%20K\%C3\%B6rfez,56\%2C4\%20milyar\%20dolar \%20oldu (Erişim Tarihi: 12.02.2021); Fakat her ne kadar Türkiye'nin diş ticaret hacminde önemli bir yer tutuyor olsa da 2020 yılı itibariyle ihracat yapılan ülkeler siralamasında Arap kalpgâhını 21. Sırada BAE temsil edebilmektedir. İlgili rapor için bknz. "2020 Yılı İhracatımızda İlk 20 Ülke", Türkiye İhracatçılar Meclisi, https://tim.org.tr/tr/ihracatrakamlari (Erişim Tarihi: 12.02.2021)

54 "Katar'a Ambargo Uygulayan Ülkelerden Skandal Talep", Sabah, 23.06.2017, https://www.sabah.com.tr/dunya/2017/06/23/korfez-ulkelerinden-flas-turkiye-talebi 
kuşkusuz Türk büyük stratejisi açısından da üzerinde düşünülmesi gereken bir trenddir. Trump yönetiminin özellikle Suudi Arabistan ve BAE ile geliştirdiği ilişkiler, salt İran'ın sergilediği tehdit edici konumdan ötede anlamlara sahiptir. Yukarıda da anıldığı ölçülerde Arap kalpgâhı, kuzey sahillerinden Akdeniz'e çıkabilmek için İsrail'e ihtiyaç duymaktadır. Bunu yaparken de Amerikan gücüyle de sıra dışı bir iş birliğine gidilmiş ve özellikle astronomik silah alım anlaşmaları imzalanarak, Amerikan desteği de garanti edilmek istenmiştir. Lakin bu trend, bölgesel aktörlerin yoğun tepkisini çekmiş ve Arap kalpgâhının gelecekteki istikrarına yönelik soru işaretleri oluşturmuştur.

Biden yönetiminin, selefinin tercihleri hilafına uygulamalara gidebilecek bir dış politika perspektifine sahip olması Arap kalpgâhında yaşanan tereddütleri de köpürtmüştür. Özellikle Yemen'deki iç savaşta Suudi Arabistan ve BAE'nin oynadıkları rol, Amerikan yönetimi tarafından güçlü bir biçimde eleştirilmekte ve bu savaşa verilen Amerikan desteğinin son bulacağ belirtilmektedir. $^{55} \mathrm{Bu}$ çerçevede düşünüldüğünde, Biden yönetiminin Arap kalpgâhını İsrail'e daha da bağımlı kılacak bir doğrultuda hareket ettiği tespit edilebilir. Hâlihazırda da İsrail'le yürütülen askerîistihbari iş birliğinin oluşturduğu zeminde, Amerikan yönetiminin insan haklarını öne sürerek Arap devletlerine karşı edineceği yeni mesafeli pozisyon sebebiyle, Arap kalpgâhı kuzey sahilleriyle bütünleşmeye zorlanabilir. Unutulmamalıdır ki İsrail'in yabancı ülkelere silah satışlarında, muhatap ülkelerdeki insan haklarının düzeyiyle ilgili bir ön şartı bulunmamaktadır. Bu çerçevede düşünüldüğünde, Yemen'deki Suudi Arabistan-BAE askerî müdahalesinin herhangi bir netice alamadan bölgeden ayrılması ve Amerikan yönetiminin güçlü desteğinden mahrum kalması, Arap kalpgâhındaki güçlerin kuzey rimlandiyle entegrasyonunu güçlendirebilir. Bu açıdan bakıldığında, İsrail, Arap kalpgahına ulaşmanın ve onu yönlendirmenin/kısıtlamanın temel aracı haline dönüşebilir.

Türk büyük stratejisi açısından bakıldığında, Arap kalpgâhında etkin olabilmenin yolları jeopolitik düzlemde birden çok seçeneğe sahiptir.

55 "U.S. Blinken, Saudi Foreign Minister Discuss Yemen, Defense", The Guardian, 11.02.2021, https://www.theguardian.pe.ca/news/world/us-blinken-saudi-foreign-ministerdiscuss-yemen-defense-551259/ (Erişim Tarihi: 14.02.2021) 
Bu bağlamda kuzey sahillerinde İsrail, güney sahillerinde ise Yemen ve Umman, Arap kalpgâhında etkinliğin önemli unsurları olarak gözlemlenmektedir. Ayrıca Kızıldeniz'de Bab-ül Mendep Boğazı'nın giriş ve çıkışını kontrol edebilecek bir pozisyon elde etmek Arap kalpgâhının kitlesel yerleşiminin kıyı kentlerinde olduğu da hesaba katılırsa, oldukça kritik bir rol oynayabilir. Bu bağlamda Somali'deki Türk askerî varlığına ek olarak Cibuti ve Eritre hattında da etkinlik göstermek hedeflenebilir. Söz konusu devletlerin küçük ve uluslararası politika açısından göreceli olarak etkisiz devletler olması sahip oldukları jeopolitik ve jeostratejik önemi azaltmamaktadır. Günümüzde özellikle Cibuti'de hemen her büyük gücün varlık gösterdiği düşünüldügünde Türk büyük stratejisi açısından Kızıldeniz'in kuzeyine nüfuz edebilmenin başat koşullarından biri olarak Cibuti-Eritre hattında varlık göstermek gerektiği anlaşılabilir.

Arap kalpgâhının güneydoğu sahillerinde de benzer bir pozisyon elde etmek jeopolitik açıdan bir gereklilik olmakla birlikte, Umman ve İran'ın politik pozisyonları göz önünde bulundurulduğunda bunun henüz pek mümkün görünmediği tespit edilebilir. Özellikle Umman Krallığı, takip ettiği tarafsızlık politikasına ulusal istikrarı açısından stratejik bir önem atfetmektedir. Ayrıca Hürmüz Boğazı'nda varlık gösterebilmek adına İran'la ilişkilerin geliştirilmesi kuşkusuz optimum bir tercih olmakla birlikte, iki ülke ilişkilerindeki sorunlu başka konular sebebiyle, böylesi bir gelişme pek mümkün görünmemektedir. İki ülkenin tarihsel olarak rekabetçi bir ilişki koduna sahip olması İran'ın Türkiye'ye Hürmüz Boğazı'nda etkinlik kazanabilmesi adına alan açmasını olasılıklar kümesinden çıkartmaktadır. Ayrıca İran, bölgesel bir hegemonya hedefiyle kurguladığı dış politikası sebebiyle de bir başka hegemonik güç potansiyeline sahip Türkiye'nin imkân kazanmasını istemeyecektir. Bu bağlamda, Basra Körfezi ve dolayısıyla Hürmüz Boğazı'nda bir dereceye kadar etkinlik sağlayabilmek için yakın ilişkilere sahip olunan Katar'ın politik olarak istikrarlı bir patikada ilerlemesi ve bu ülkede bulunan askerî varlığın devamlılığı önem arz etmektedir.

\section{Sonuç}

Son yıllarda Arap yarımadasının jeopolitiğinde yaşanan radikal dönüşümler sebebiyle yapılan bu çalışma, hem Arap yarımadasında öne çıkan aktörlerin kapasitelerini ölçeklendirmek hem de Türk büyük stratejisinin bölgeye dönük amaçlarına optimum güzergâhlar sunmak hedefindedir. Bu bağlamda düşünüldüğünde yukarıda detaylı ve analitik 
bir biçimde anlatılmaya çalışılan jeopolitik olguların nihai envanterini çıkartmak gerekmektedir.

Arap kalpgâhı olarak tanımlanan coğrafi alanı kontrol edebilmenin başat koşullarından biri, Arap rimlandi olarak tarif edilen alanda denetim kurabilmekten geçmektedir. Bu çerçevede düşünüldüğünde yukarıda da etraflıca açıklandığı üzere; kuzey sahillerinde İsrail ve güney sahillerinde de Yemen ve Umman'da kurulabilecek bir denetim, Arap kalpgâhını kontrol edebilmenin önemli unsurlarıdırlar.

Ayrıca Arap kalpgâhını çevreleyen ve açık denizlere ulaşımını sağlayan deniz yolları da denetim kurmanın önemli araçlarıdırlar. Bu bağlamda, kuzeyde açılması planlanan muhayyel Eilat-Aşdod kanalı ve Süveyş Kanalı, güneyde ise Bab-ül Mendep Boğazı ile Hürmüz Boğazı, Arap kalpgâhının açık denizlere çıkabilmesine imkân veren ya da sınırlayan suyolları olarak bölgenin denetimi açısından yine kritik önemdedirler. Bu bağlamda sırasıyla İsrail, Mısır, Cibuti, Eritre, Somali, Umman ve İran, Arap kalpgâhının ulaşım hatlarını kesebilecek kapasiteye sahip görünmektedirler.

Bir diğer unsur olarak da hem batıda Kızıldeniz hem de doğuda Basra Körfezi’nin kıyıdaş devletleri, Arap kalpgâhının denetimini sağlayabilecek aktörler olarak görülebilirler. Bu çerçevede, Kızıldeniz'e kıyıdaş devletlerden Mısır, Sudan, Eritre, Cibuti ve Basra Körfezi'ne kıyıdaş devlet olarak da İran, Arap kalpgâhının imkânlarını/sınırlarını belirleyen bir jeopolitik konuma sahiptirler.

Yukarıda anlatılanlar ışı̆̆ında Türk büyük stratejisinin de gözden geçirilmesi gerekmektedir. Bu çerçevede Türkiye, şayet Arap kalpgâhında etkin bir güç olarak konumlanmak ve bu coğrafi alandaki devletleri ulusal çıkarları doğrultusunda yönlendirebilmek istiyorsa isimleri anılan devletlerde politik, askerî ve ekonomik nüfuzunu ve kapasitesini arttırmak durumundadır. Ancak böylesi bir girişim, Arap kalpgâhında etkinlik sağlama ve bir dereceye kadar da denetim kurma imkânı verecektir. Suriye'de uzun yıllara yayılan iç savaş ortamı, kısa ve orta vadede Şam'da güçlü bir merkezi yönetimin tesis edilmesi olasılığının düşüklüğü ve Amerikan işgali sonrası (2003) Irak'ta oluşan İran etkisi hesaba katıldığında; Arap kalpgâhına ulaşmanın ve bu coğrafyada jeopolitik bir aktör olarak konumlanmanın yolu, yukarıda anılan devletlerle ilişkileri yoğunlaştırmaktan ve mümkün olduğu ölçülerde bu 
coğrafyalarda askerî olarak da varlık gösterebilmekten geçmektedir.

Ayrıca Türkiye, Osmanlı İmparatorluğu dönemini de kapsayacak ölçülerde tarihsel olarak daha ziyade kara gücüyle eşleştirilmiş ve ünlenmiş bir ordu yapılanmasına sahiptir. Son yıllarda donanmanın geliştirilmesi yeni deniz araçlarıyla teçhiz edilmesi ve içerisinden entelektüel iddialara sahip subayların çıkması elbette ki Türkiye'nin denizlerde de ağırlığını hissettireceği bir konuma doğru ilerlediğine delalet etmektedir. Arap yarımadasının jeopolitik analizinde de açıklandığı üzere, Türk büyük stratejisinin bölgesel bir etkinliği bütüncül bir biçimde kurabilmesi de ancak kara-deniz gücünü optimum bir dengede tutabilmesiyle mümkündür. Arap denizleri, boğazları ve kanallarında ve ayrıca kuzey ve güney Arap rimlandlerinde etkin bir pozisyon alabilmek kuşkusuz her şeyden evvel dikkate değer bir deniz gücüne sahip olmaktan geçmektedir. Bu bağlamda düşünüldüğünde Türk büyük stratejisinin Arap kalpgâhındaki etkinlik kapasitesi, ancak kara ve deniz güçlerinin efektif ve eşgüdümlü konumlandırılmasıyla şekillenebilir ve hacim kazanabilir.

Bu çalışmanın kaleme alındığı zaman diliminde Arap kalpgâhı, kuzey rimlandini teşkil eden İsrail ile yaşadığı normalleşme ve entegrasyon süreci neticesinde, Akdeniz'de Türk stratejisine meydan okuyucu bir pozisyon sergilemeye başlamıştır. Özellikle Yunanistan-Güney Kıbrıs Rum Yönetimi ikilisinin başını çektiği ve İsrail'in cesaretlendirdiği bir diplomatik-askerî süreçle Arap kalpgâhı, Doğu Akdeniz bölgesinde askerî tatbikatlara katılmış ve çeşitli düzeylerde diplomatik angajmanlara girmiştir. Bu süreçlerin en belirgini olarak Philia Forum; Suudi Arabistan, Birleşik Arap Emirlikleri ve Bahreyn'in Doğu Akdeniz'de varlık göstermelerinin tescili hükmündedir. Türk büyük stratejisi açısından konuya yaklaşıldığında yukarıda etraflıca analizi yapılan Arap kalpgâhına yönelik uygulanacak sınırlandırıcı politikalar, Türkiye'nin Doğu Akdeniz politikalarında da kazanım sağlamaya yardımcı olabilecektir.

\section{Summary}

The Arabian Peninsula states had played an important role throughout the 20th century. Particularly the Saudi Arabia, the leading country in the region, is very famed related to its very concrete relations with the United States (U.S.). In Cold War, Saudi foreign policy rested 
upon U.S. dominance in the region excluding a few deteriorating actions towards the relations of both.

In the aftermath of the Six Day War, Israel's occupation of Jerusalem raised concern of Saudis and the breakout of a fire at the site of Haram alSharif triggered the claim of Islamic leadership with an Islamist discourse by Saudis. Shortly after, in another case, especially the Yom Kippur War in 1973, as a result of the U.S. aid to Israeli part, Arab countries showed a huge rage towards the American stance. They backfired with their unique diplomatic leverage, increased the petroleum prices by decreasing the total production. At the time, the Western countries were aware of their vulnerability in terms of economic security.

Arabian Peninsula states usually obeyed the rules of the hegemonic power in the region. Generally speaking, throughout the Cold War and beyond, the U.S. had produced security for them in the meaning of regime security and territorial integrity. In turn, the Arabian Peninsula states paid the bill with the stability of energy production in tolerable prices. However, today, such kind of relationship seems disappearing due to the waning hegemony of the U.S. regionally and the declining significance of petroleum as a main source of energy. Additionally, Arab Spring, Nuclear Agreement (JCPoA), and Abraham Accords have been changed the political landscape of the region up to now. We need to analyze the new parameters by analyzing the Arabian Peninsula, first in a geopolitical manner. To do so, we can improve the capacity of Turkish grand strategy.

Classical geopolitics has been treated as an old fashion mode of understanding/explanation of International Relations for a long while. However, the most basic concepts and theories are surprisingly very well suited to the Arabian Peninsula geopolitics. In this study, with references to Mackinder's Heartland, Spykman's Rimland and Mahan's Sea Dominance theories, the Arabian Peninsula geopolitics will be rewritten. First, Arabian heartland consists of Saudi Arabia at the core and also the small Gulf monarchies, United Arab Emirates and Bahrain. They truly constitute a geopolitical block. Secondly, in the south, Yemen and Oman and in the north, Israel compose the Arabian rimlands. With reference to the seas and choke points surrounding the region, respectively, Egypt, Sudan, Eritrea, Djibouti, Somalia, and Iran are also the main players in the stability of Arabian Peninsula. 


\section{Ceyhun ÇİÇEKÇİ}

This study aims developing responses to the newly emerged Arabian challenges to Turkish positions. Today, the Arabian Peninsula states are very effective in the regions of Middle East and East Mediterranean both. This is a very new phenomenon. Thanks to the normalization process amongst Israel and most of the Arabian Peninsula states, abovementioned regions merged rapidly. However, the Arabian Peninsula states engaged in a kind of alliance with the anti-Turkish forces. Keeping the Turkish grand strategy debates in mind, this study gives some clues in driving the Arabian Peninsula states nearer to the Turkish interests. Eventually, this study concludes with a general proposal, which consists of the coordination of both land and sea capacities, which may bring success to Turkish grand strategy.

\section{Çatışma Beyanı:}

Makalenin ile ilgili herhangi bir kurum, kuruluş, kişi ile çıkar çatışması bulunmamaktadır.

\section{Kaynakça \\ Kitaplar}

BRZEZINSKI, Zbigniew; The Grand Chessboard: American Primacy and Its Geostrategic Imperatives, Basic Books, 1997.

DOCKRILL, Michael L. and Michael F. Hopkins; The Cold War, 1945-1991, Palgrave Macmillan; Second Edition, New York, 2006.

DODDS, Klaus; Geopolitics: A Very Short Introduction, Oxford University Press, Oxford, 2007.

GERGES, Fawaz A.; "The Transformation of Arab Politics: Disentangling Myth From Reality", The 1967 Arab-Israeli War: Origins and Consequences, Ed. by. Wm. Roger Louis \& Avi Shlaim, Cambridge University Press, New York, 2012.

HILL, Ginny; Yemen Endures: Civil War, Saudi Adventurism and the Future of Arabia, Oxford University Press, U.S.A., 2017.

KECHICHIAN, Joseph A.; Oman and the World: The Emergence of an Independent Foreign Policy, RAND, Santa Monica, 1995.

KERR, Malcolm; The Arab Cold War 1958-1967, Oxford University Press; Second Edition, 1967.

MACKINDER, H. J.; Democratic Ideals and Reality: A Study in the Politics of Reconstruction, Henry Holt and Company, New York, 1919. 
İbrahim Anlaşmaları Sonrası Arap Yarımadasının Jeopolitik Analizi ve Türk Büyük Stratejisinin İmkânları/Kısıtları

MAHAN, Alfred Thayer; The Influence of Sea Power Upon History, 1660-1783, Cambridge University Press, Cambridge, 2011.

Part III, "Straits Used for International Navigation", United Nations Convention on the Law of the Sea, Nova Science Publishers, New York, 2009.

SPYKMAN, Nicholas J.; America's Strategy in World Politics: The United States and the Balance of Power, Harcourt Brece and Company, New York, 1942.

SPYKMAN, Nicholas J.; The Geography of the Peace, Harcourt Brace and Company, New York, 1944.

YAQUB, Salim; Containing Arab Nationalism: The Eisenhower Doctrine and the Middle East, The University of North Carolina Press, U.S.A., 2004.

Makaleler

AKTÜRK, Şener; “Turkey's Grand Strategy as the Third Power: A Realist Proposal”, Perceptions: Fournal of International Affairs, Cilt 25 Say1 2, p. 152-177.

BARAK, Eitan; "Between Reality and Secrecy: Israel's Freedom of Navigation Through the Straits of Tiran, 1956-1967”, Middle East Fournal, Vol. 61, No. 4, Autumn, 2007, p. 657-679.

HANCOCK, Kathleen J. and Vlado Vivoda; "International Political Economy: A Field Born of the OPEC Crisis returns to its Energy Roots", Energy Research E Social Science, Vol. 1, March 2014, p. 206-216.

HAYNES, Jeff; “Transnational Religious Actors and International Politics", Third World Quarterly, Vol. 22, No. 2, 2001, p. 143-158.

HEIDEN, Patrick Van Der and Alex Krijger; "The Saudi-Iranian Rivalry: An Ominous Zero-Sum Game for Supremacy”, Atlantisch Perspectief, Vol. 42, No. 2, 2018, p. 11-15.

MACKINDER, H. J.; "The Geographical Pivot of History”, The Geographical fournal, Vol. 23, No. 4, April 1904, p. 421-437.

MANN, Joseph; "King Faisal and the Challenge of Nasser's Revolutionary Ideology", Middle Eastern Studies, Vol 48, Iss 5, 2012, p. 749-764.

\section{Internet Kaynaklari}

"2020 Yilı İhracatımızda İlk 20 Ülke”, Türkiye İhracatçılar Meclisi, https://tim.org.tr/tr/ihracat-rakamlari (Erişim Tarihi: 12.02.2021)

"Can MBS's Neom Translate into the Saudi Forging Ties with Israel?", TRT World, https://www.trtworld.com/magazine/can-mbs-s-neom-translate-into-the-saudis-

forging-ties-with-israel-38974 (Erişim Tarihi: 13.02.2021)

"Egypt's Suez Canal Blocked by Huge Container Ship", BBC, https://www.bbc.com/ news/world-middle-east-56505413 (Erişim Tarihi: 07.07.2021)

"Egypt Vexed By Israel, UAE Plans for 'Rival Suez Canal", The New Arab, https://english.alaraby.co.uk/english/news/2020/10/2/egypt-vexed-by-israeli-emiratiplans-for-rival-suez-canal (Erişim Tarihi: 14.02.2021)

"Iran Threatens Arab National Security: Saudi, Yemeni Ministers", Arab News, https://www.arabnews.com/node/1732326/middle-east (Erişim Tarihi: 13.02.2021)

"Iran-Allied Houthis in Yemen Fire Missiles at Saudi Capital", Reuters, https:/www.reuters.com/article/us-saudi-security/saudi-arabia-says-it-interceptshouthi-missiles-over-riyadh-idUSKBN1IA100 (Erişim Tarihi: 10.02.2021)

"Israel to Begin Promoting Railway Linking Haifa Seaport with Saudi Arabia", The Times of Israel, https://www.timesofisrael.com/israel-to-begin-promoting-railwaylinking-haifa-seaport-with-saudi-arabia/ (Erişim Tarihi: 12.02.2021) 


\section{Ceyhun ÇİÇEKÇİ}

"Katar'a Ambargo Uygulayan Ülkelerden Skandal Talep", Sabah, https://www.sabah.com.tr/dunya/2017/06/23/korfez-ulkelerinden-flas-turkiye-talebi “Ministers Discuss Trans-Gulf Railway Project”, Arab News, https://www.arabnews. com/node/1782521/saudi-arabia (Erişim Tarihi: 12.02.2021)

"New Naval Base Boosts Egypt Presence in the Red Sea", The Arab Weekly, https://thearab weekly.com/new-naval-base-boosts-egypts-presence-red-sea (Erişim Tarihi: 06.07.2021)

"Son Hamlenin Ardından Ortaya Çıktı! İşte Türk Üçgeni...”, Milliyet, https://www.milliyet.com.tr/gundem/son-hamlenin-ardindan-ortaya-cikti-iste-turkucgeni-2580269 (Erişim Tarihi: 14.02.2021)

"The UAE is Building a New Airbase off Yemen to Control and Safeguard Red Sea Shipping”, DEBKA, https://www.debka.com/the-uae-is-building-a-new-airbase-offyemen-to-control-and-safeguard-red-sea-shipping/ (Erişim Tarihi: 07.07.2021)

"Türkiye, Ortadoğu ve Körfez Ülkeleriyle İşbirliğini Büyütüyor”, TRT Haber, https://www.trthaber.com/haber/ekonomi/turkiye-ortadogu-ve-korfez-ulkeleriyle-ticaretinibuyutuyor-362796.html\#: : :text=T\%C3\%BCrkiye'nin\%20Ortado\%C4\%9Fu\%20ve\%20

K\%C3\%B6rfez,56\%2C4\%20milyar\%20dolar\%20oldu (Erişim Tarihi: 12.02.2021);

"U.S. Blinken, Saudi Foreign Minister Discuss Yemen, Defense", The Guardian, https://www.theguardian.pe.ca/news/world/us-blinken-saudi-foreign-minister-discussyemen-defense-551259/ (Erişim Tarihi: 14.02.2021)

ALKHEREIJI, Mohammed A.; "Saudi Arabia Embraces a Different Future with NEOM", The Arab Weekly, https:/thearabweekly.com/saudi-arabia-embracesdifferent-future-neom (Erişim Tarihi: 13.02.2021)

ATLI, Altay; "China, Israel and the Geopolitics of Seaports", The Diplomat, https://thediplomat.com/2019/07/china-israel-and-the-geopolitics-of-seaports/ (Erişim Tarihi: 12.02.2021)

BARKAT, Amiram; "Israel to Propose Saudi-Israel Oil Pipeline", Globes, https://en.globes.co.il/en/article-israel-to-propose-saudi-israel-oil-pipeline-1001343034

(Erişim Tarihi: 15.02.2021)

BELLO, Lupus De; “Kenya is Somalia's Latest Victim in Region of Failed States”, The Conversation, https://theconversation.com/kenya-is-somalias-latest-victim-inregion-of-failed-states-18582 (Erişim Tarihi: 11.02.2021)

CORDESMAN, Anthony H.; "America, Saudi Arabia, and the Strategic Importance of Yemen”, Center for Strategic and International Studies, https:/www.csis.org/analysis/ america-saudi-arabia-and-strategic-importance-yemen (Erişim Tarihi: 08.02.2021)

FAHMY, Viola; “Arab-African Alliance Announced in Riyadh”, Anadolu Agency, https://www.aa.com.tr/en/middle-east/arab-african-alliance-announced-in-

riyadh/1694211 (Erişim Tarihi: 10.02.2021)

FRANTZMAN, Seth J.; "Socotra: How a Strategic Island Became Part of a Gulf Power Struggle”, The Jerusalem Post, https:/www.jpost.com/middle-east/socotra-how-a-strategicisland-became-part-of-a-gulf-power-struggle-553599 (Erişim Tarihi: 06.07.2021)

GUENOT, Marianne; "The U.S. had a Plan in the 1960s to Blast an Alternative Suez Canal through Israel using 520 Nuclear Bombs", Business Insider, https://www.businessinsider.com/us-planned-suez-canal-alternative-israel-blast-withnuclear-bombs-1960s-2021-3 (Erişim tarihi: 06.07.2021)

HASSAN, Khalid; ““Egypt Concerned UAE-Israeli Pipeline Project will Affect Suez Canal", Al Monitor, https://www.al-monitor.com/originals/2021/02/egypt-israel-uaeashkelon-eilat-oil-pipeline-suez-canal.html (Erişim Tarihi: 06.07.2021) 
İbrahim Anlaşmaları Sonrası Arap Yarımadasının Jeopolitik Analizi ve Türk Büyük Stratejisinin İmkânları/Kısıtları

KNIGHTS, Michael and Farzin Nadimi; "Curbing Houthi Attacks on Civilian Ships in the Bab Al-Mandap”, The Washington Institute, https://www.washingtoninstitute.org/policy -analysis/curbing-houthi-attacks-civilian-ships-bab-al-mandab (Erişim Tarihi: 10.02.2021)

LOWENSTEIN, Julie; "US Foreign Policy and the Soviet-Afghan War: A Revisionist History”, Harvey M. Applebaum '59 Award, 2016, https:/elischolar.library.yale.edu/cgi/ viewcontent.cgi ?article $=1045 \&$ context $=$ applebaum_award (Erişim Tarihi: 12.02.2021)

NATIONAL SECURITY ARCHIVE, The Charge in the Soviet Union (Kennan) to the Secretary of State, https://nsarchive2.gwu.edu//coldwar/documents/episode-1/kennan.htm (Erişim Tarihi: 12.02.2021)

NATO, “Operation Ocean Shield", https://mc.nato.int/missions/operation-oceanshield (Erişim Tarihi: 13.02.2021)

NORDLAND, Rod; “Saudi Arabia Promises to Aid Egypt's Regime”, The New York Times, https://www.nytimes.com/2013/08/20/world/middleeast/saudi-arabia-vows-toback-egypts-rulers.html (Erişim Tarihi: 06.02.2021)

RABINOVITCH, Ari and Tova Cohen; "Israeli Pipeline Company Signs Deal to Bring UAE Oil to Europe", Reuters, https://www.reuters.com/article/us-emirates-israelpipeline/israeli-pipeline-company-signs-deal-to-bring-uae-oil-to-europe-

idINKBN275155 (Erişim Tarihi: 06.07.2021)

REZEG, Ali H. M. Abo; "Iran Renews Threat to Close Strategic Strait of Hormuz", Anadolu Agency, https://www.aa.com.tr/en/americas/iran-renews-threat-to-closestrategic-strait-of-hormuz/1460108 (Erişim Tarihi: 12.02.2021)

WALSH, Declan; “Amid U.S. Silence, Gulf Nations Back the Military in Sudan's Revolution", The New York Times, https://www.nytimes.com/2019/04/26/world/ africa/sudan-revolution-protest-saudi-arabia-gulf.html (Erişim Tarihi: 05.02.2021)

YAKIŞ, Yaşar; "How the Khartoum Coup will Affect Turkey-Sudan Relations", Arab News, https://www.arabnews.com/node/1485706 (Erişim Tarihi: 14.02.2021) 